\title{
HISTOLOGICAL STUDY OF SKIN GRAFT ON THE BONE IN MASTOID CAVITY.
}

By

\section{H. ENOSHIMA}

From the Department of Oto-Rhino-Laryngology, Nagoya University School of Medicine (Director Prof. Goto M.D. Prof. Tauchi M.D.)

Histological studies of 133 skin grafts in bulla ossea of rabbits were made as one of the fundomentaluts dies of tympanoplasty. The examination was done on 1 st, 2nd, 3rd, 5th, 8th, 15th, and 30th postoperative day. The results were as follows:

New epithelium was regenerated under the degenerated old grafts on 3 rd and 5 th. day. The epithelienr was thiekened after 8th day: Theepithelialization was disturbed by infection, excessive pressure, dryness and insufficient immobilization of the grafts.

When mucus membrane was prsent, cyst formation was frequent and the grafts were scarcely taken, On the periosteum, the grefts were easily taken and epithelialization was safisfactory. On the bone without periosteum, the grafts were difficult to be taken and epithelialization was also disturbed. When the bone was injured prier to the graft, thick layer of granulation tissue was seen between the skin and bone. Regeneration of the bone was seen on 5th day but organization of the bore fissue was not seen even on 30th day.

Thick grafts contained many hair follicles and sebaceous glands which became at rophied aad formed vacuoles later. There fore, thin grafts were thonght to be better than thick ones.

\section{骨面皮虐移植に関する組織学的研究}

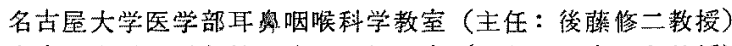

名古屋大学医学部策二病理 学教窒（主任：因内 久教授）

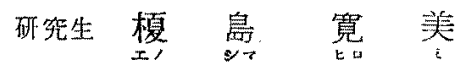

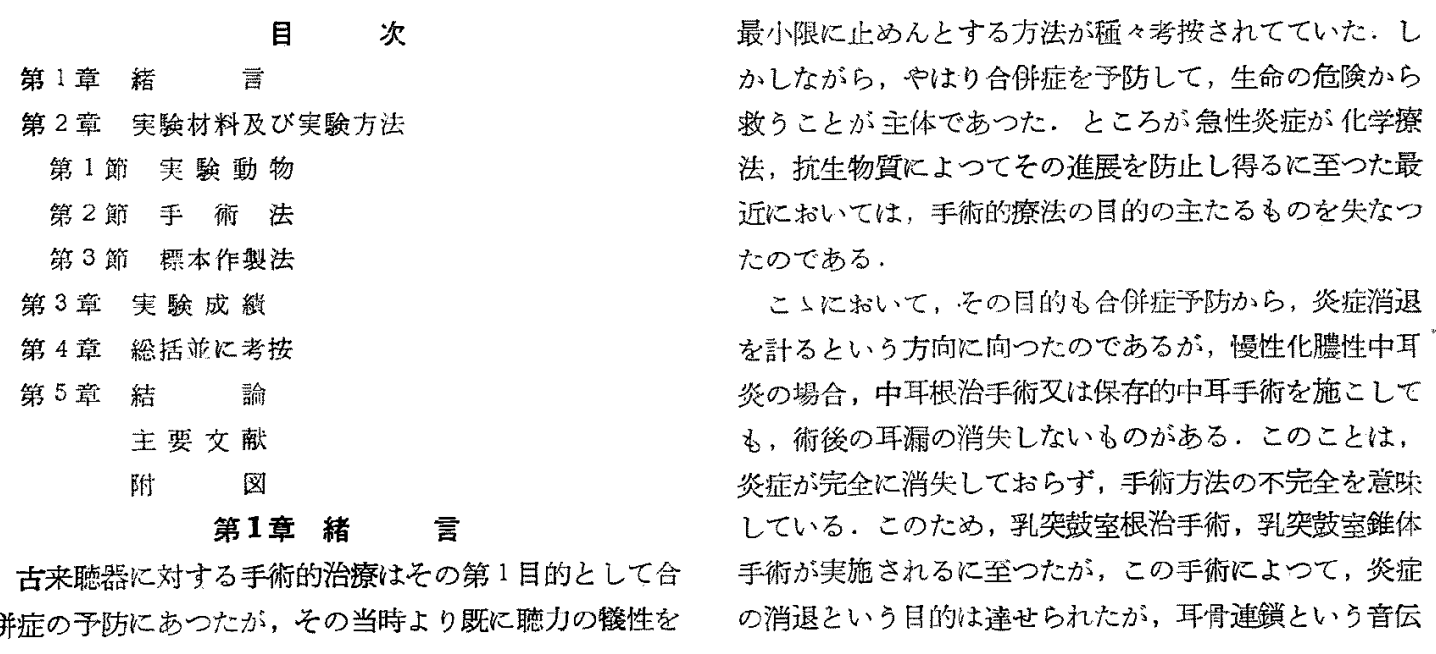




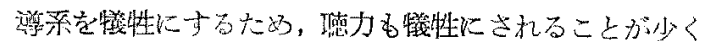
ない.

かくして古くから行かれている保存的于術が㥁力を㺟 性にしないという缺味で重要視されてきた。そこで焱症 老消退好しぬて，聴力总保存する手術法といらことが考 点られるのである。

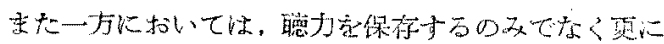
詼復せしめんとする努力が払和えてきた，即ち Lempe

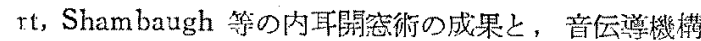

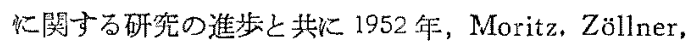
Wullstein の方法が相次いて発表され，1953 年、1954 年には，Zöllner，Wullstein は自己の 手術法を整理し て発表, Mundnich む，1953 年独自の孚術法発発表し ている、我が国に括いては，1952 年後藤教授が始めて 発表され，これを「聴力增進中耳根治手術」と命名さ

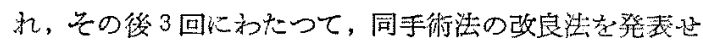

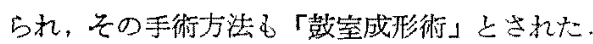

しかしてこの手術方法の基碟的研究の一翼として，愁

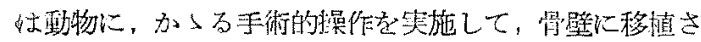

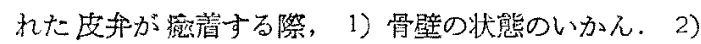

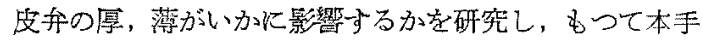
術における骨面への禃皮の最良条件を求めんとした。

\section{第 2 龺 実験材料及び実験方法}

第 1 節 実嗝動物

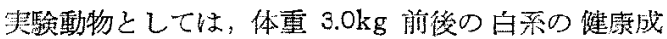
熟家医を用いた。

第2節 䒠龄方法

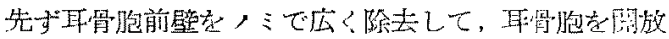
した，次いで耳㓩狍内壁は，1）粘朕を残するの，2） 粘膜を除去して骨慕を残寸もの，3）粘膜及び骨膜を除 去して骨は倁つけないるの，4）粘滕及び骨膜を经去し て骨も表面を傷つけたもの，以上4孀の状態になる上う に意図して，それぞれ，1）耳骨胞を開族したぐけ，2） ガーゼ片で耳骨胞内部を拭く，3）锁题で軽く内部总摆

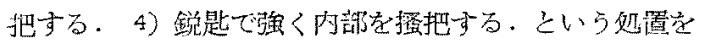
した。

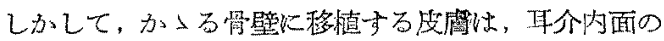

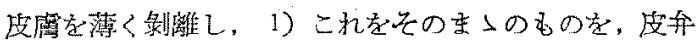

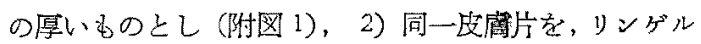
氏液を入れた隇菌シャーレ中で，别刀をるつてできるた

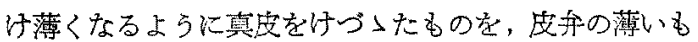
のとした (四2).

前記方法で奶置した耳骨胞内壁に，これら皮弁を㧊
き，感染䂆方の目的老もつて，テトシサイクリンの粉末 を附着したがーゼ片を栓塞して手術学終つた。

涵後, 毎日寒験䣦物の創面及び健康状態に留意し, ガ

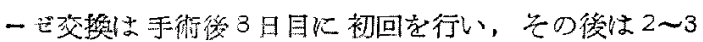
日の間隔で行つだ。このがーぜ交換も感染予防のた的

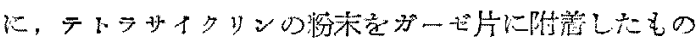
主港用した。

第3 䈟 標本作擎法

以上の手術を行つて，1)粘膜を残したもの，2）粘

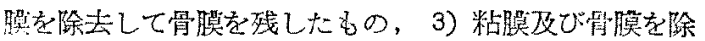
洪して骨に損傷のないもの，4）粘膜及び骨膜を除去し 雨に骨まで傷つけたものの各 4 種類の勘物を，更にそれ ぞれ植皮後，1日，2日，3日，5日，8日，15日，30日 の日数経䢔後に断頭して，耳骨胞のみを剔出し，10\%フ オルマリン液で固定，オオン交換樹脂で脱灰し，水洗， 補強アルンールで脱水後, ッェルロイジンーパタフイン

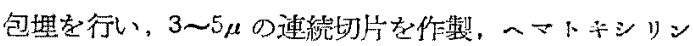
・エオジン重染舁を施し, バルサてで卦入後, 鏡検し t.

\section{第 3 草 実䠑 成績}

上記の方法によつて作劈した標本は，发弁の厚いもの では57例，皮弁の薄いものでは66例で，この133例は 移植後，1日，2日，3日，5日，8日，15日，30日の

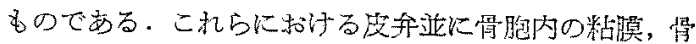
得，骨の変化を检索し心結果は次の通りで斿る。

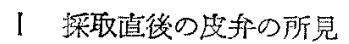

本実駼の刘照として先ず使用皮弁の組織を众索した結 果は论の上うである。表皮は最下圆にへマトキシリンに 良染した核の昨膫な円柱状の基底絸胞が 1 图認子られ，

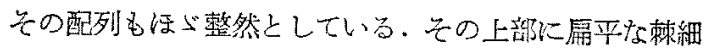
咆が 1〜2層認められるが，細胞間隐及び紐胞間橋は認 欢蜼い，家に上部の顆粒細胞は不明でェオジンに良染し た筫がある。乳頭の発奇は悪く殆ど認められない，真

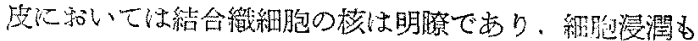
殆どなく，毛琵攻び皮脂腺怔正常である。

\section{II表留所見の分類}

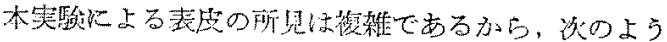
に整理した。

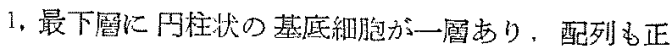
しく、へマトキシリンに良染し核も明膫である。乞の上 部に1〜2尿のや小扁平な棘細胞があり核も明膡である が，細胞間橋及び細胞間吵は認め難い，更に上部の顆粒 細胞は不明で角質に移行している。 


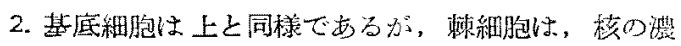

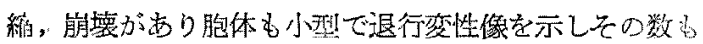
少く，大部分が每質によって置き獬克られている。

以上の，1上 2 は，基底細胞がよく保持さ机ているも ので，I型と仮称する.

3. 基底細胞にも核の濃縮があり胞体当小邢で，配列 が乱れ，ところどころに空胞化を伴う遮行变性像を示

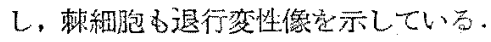

4. 基底細胞は上と同核な退行变性像定示し, 退行变

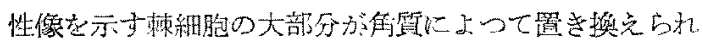
ている.

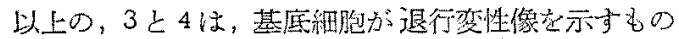
で，四型上仮称する。

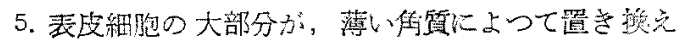
られている.

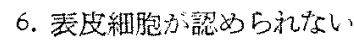

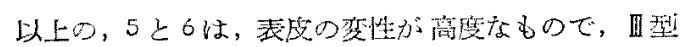
と仮称与る。

7. 最下㬝以配列の正しい染色性良好な，円柱状の基

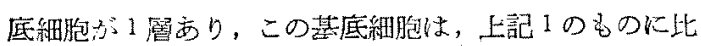

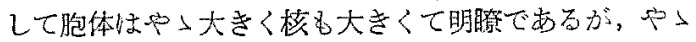

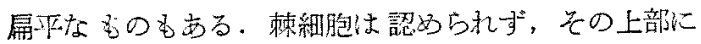

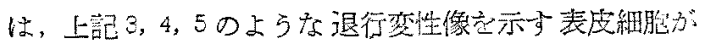
ある。

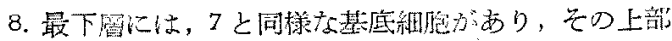

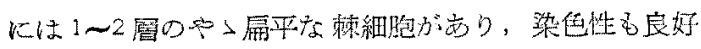

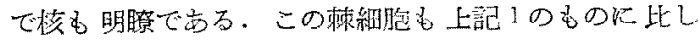
て，胞体は中大きく棪电大きい。その上部に前記了， 4，50上万度退行变性像を示寸表皮細胞がある.

以上の，7と8は基底細胞がよく保持されているが，

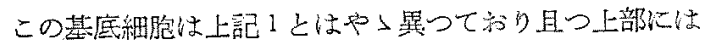

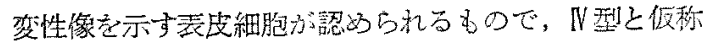
する。

9. 最下層に配列の正しい円柱状の基底稩胞が 1 層む

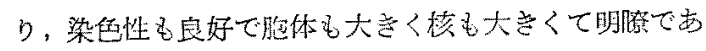

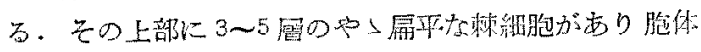

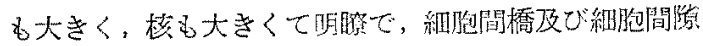

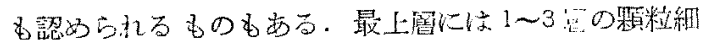

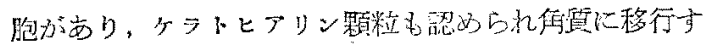

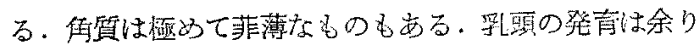
よくないが極めて良好なものもある。

この9は，表皮細胞が肥厚像を示しているものでこれ を・型と仮称する。

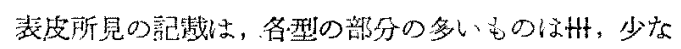

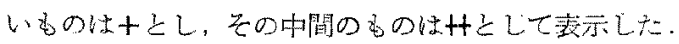

III植皮後1日の所見

この成豄は，表1に示与通りで㸝る。

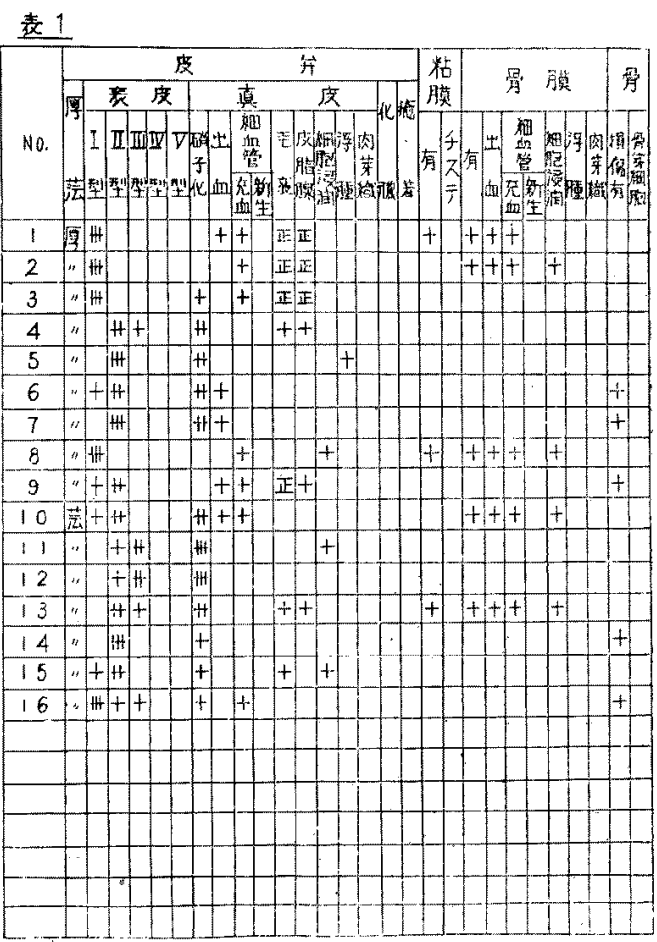

皮和の表皮恃，1型の部分の多いむの5例 (No. 1，

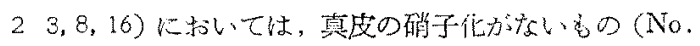

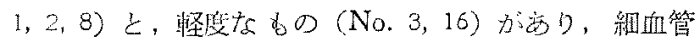

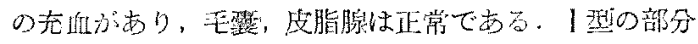
の少ない西の2例（No.9，15)では，硝子化のないも 0)(No.9) 上，碳子化が軽度なもの (No.15) 上があ

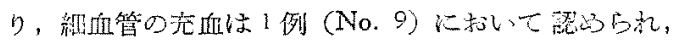

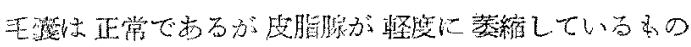

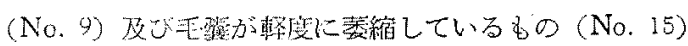

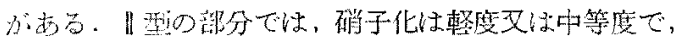

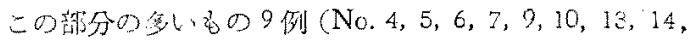

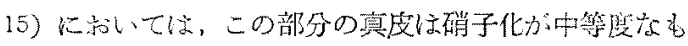

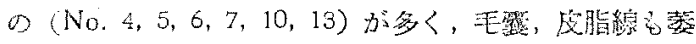

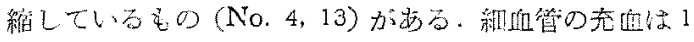

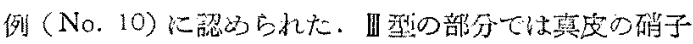
化は高湶で，この部分の象いもの2例（No.11，12）で は，練血管の充血がない，淋巴球，树中球を主とする円 
形細胞の浸潤は3例（No．8，11，15）に抽いて認めら れ，皮贲の梁層が浮脸状を呈しているものは1例（No． 5) あり, 出血のあるるの注 5 例 (No. 1, 6, 7, 9, 10)

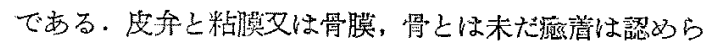
れず揬しているのみで，この部分のや1多いるのは8例 (No. 2, 3, 5, 7, 9, 11, 12, 14)で, 少小。のは2例 (No. 1，4）施り，粘膜，骨膜がなく霄に䭫傷のないる

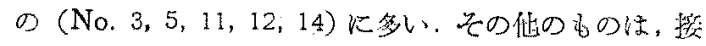

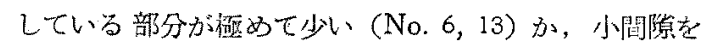
もつて離れている (No. 8, 10, 15, 16).

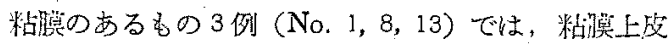

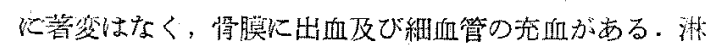
巴域，好中球主主とす万円形細胞の浸潤の西る。の （N.o 8，13）がある.氺升の表皮は厚いものではI型の

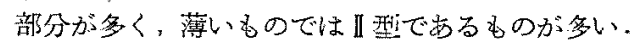

粘膜がなく，骨膜のむるもの2 例(以下骨璄のあるる

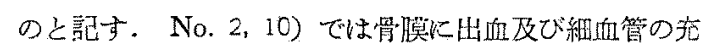
血があり，淋巴球，好中球索主上する円形細胞の浸潤が

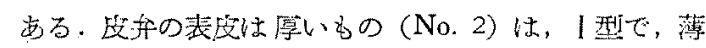
いもの (No. 10) で怔型である。

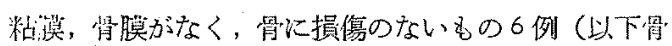
に揁傷のないものと記す. No. 3, 4, 5, 11, 12, 15)では

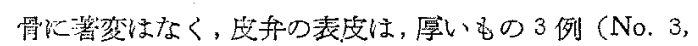

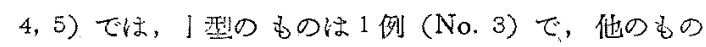
は II 型である，薄い6の3例（No.11，12，15）ては】 型が少部分あるものがl例（No．15）市り，他の部分は 西型の部分が多い。

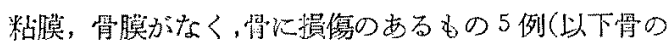

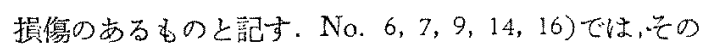

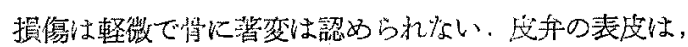
厚いるの3 例 (No. 6,7，9）では，I峾が少部分あるる

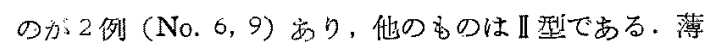

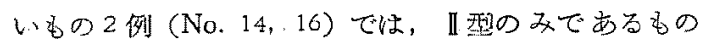
(No. 14) とI型の方るる（No. 16）とがある。

N 植皮後2日の所㫕

この成綪は，表】に示す通りである。

皮升の萇皮は，I型の部分の多いもの4例（No. 18， 19，20，26）では，真皮の硝子化はなく，少いもの3 例 (No. 17，21，27) では, 硝子化が軽度なもの(No. 17, 21) と中等度なもの（No. 27）があり，中等度なもので は，皮会内に淋巴球，好中球を主とした化膿性の細胞浸 潤觉諗める部分があり，その部分の表皮は四型である。

II型の部分が多いるの.7例 (No. 17，21，22，23，28，31，

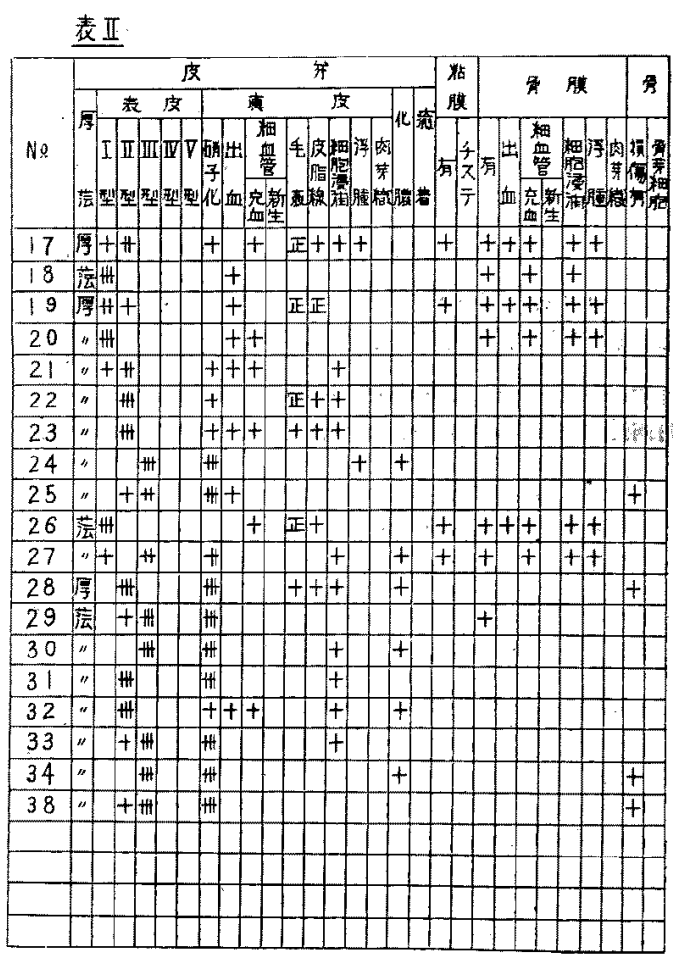

32)で恃，硝子化は軽度なむの (No. 17, 21，22，23,

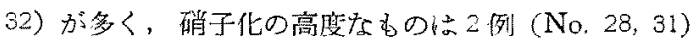

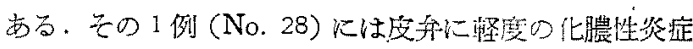

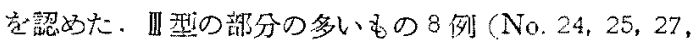

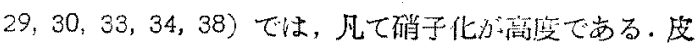
我内に出血のあるものは7例 (No．18，19，20，21，23，

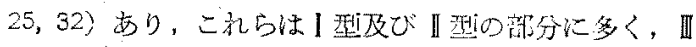

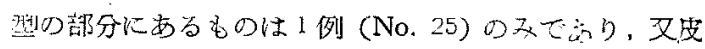
手の厚いもの(No. 18, 19，20，21，23，25) 亿多い.緗血管 の充血は6 例(No. 17, 20,21, 23, 26, 32)で，I型のあ

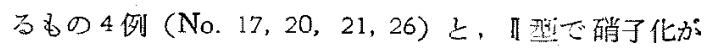

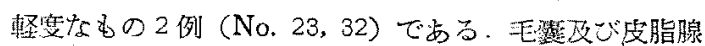
は1型である部分では正常であるが，【㑭不び型の部

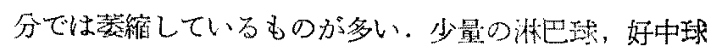
を主とする円形細胞の浸潤がある本の.(No. 17，21，22， $23,27,28,30,31,32,33)$ が场り，【些で先るもの (No. 21，22，23，28，31，32) に多いこのう立点皮が浮 腫状を呈している西のは，皮弁の厚いものに2例 (No. 17，24）あつた。皮弁に化膿性炎症を認めたものは6例 (No. 24，27，28，30，32，34)で，先の部分の表皮は四 然であるものが多く，【型であるものは1例(No. 32) 


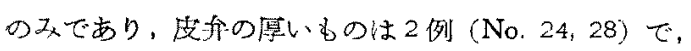
化は凡て段弁の湍いものである。

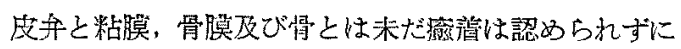
挨しているが，この部分の多いむののは? 例 (No. 17， $19,21,23,26,32,33$ ), 中>多人歹のは4 例 (No. 22, $30,31,38$ ) でこれは粘膜のあるものは3例 (No.17,

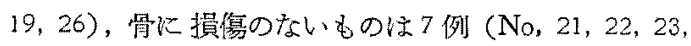

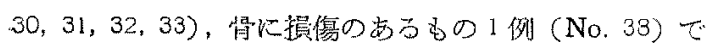

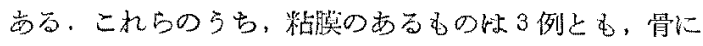

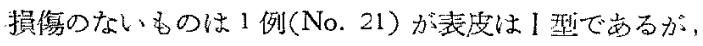

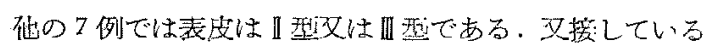
部が極めて少ないか，熦机ているものは8例 (No. 18， $20,24,25,27,28,29,34)$ で，Zの5ち表度が型で

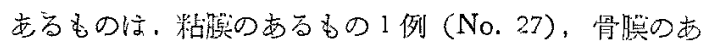
るもの2例 (No. 18,20) である.

粘膜のあるるの4例（No.17，19，26，27) では粘䐎 上发加少部分に和いて消失している6の（No. 17）があ

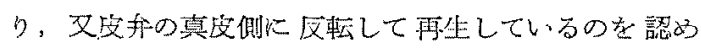
た。忽朕け浮腫状で細血管の充血があり，淋巴球，好中

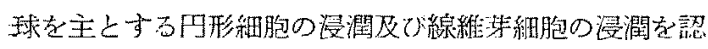

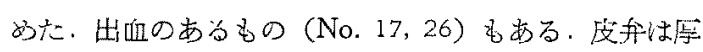
いるの (No. 19) \&, 薄いる (No. 26, 27) も表战は I型の部分の多いものがある。

骨藏のあるすの3例 (No.18，20，29) では，2例 (No. 18，20) 飞緦血管の充血，淋巴球，好中球老主と

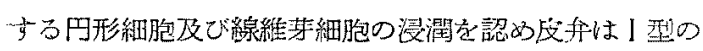

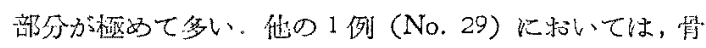

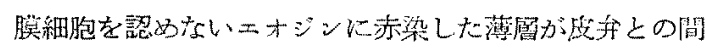

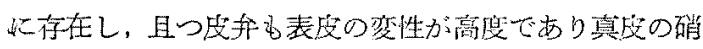
子比も甚だ高度である。

骨に撌傷のないもの8例 (No. 21，22，23，24，30，31，

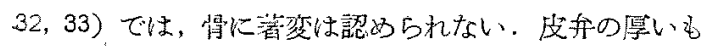
の4例 (No. 21，22，23，24) では，1型のあるもの依 1 例 (No. 21), II 型の尼のは2 例 (No. 22, 23) で, II

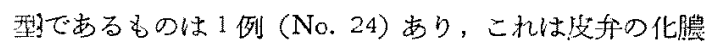

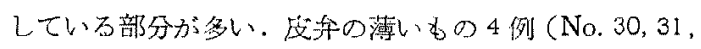
32,33) では，表发加列のbのは2例（No. 31，32)

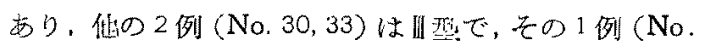

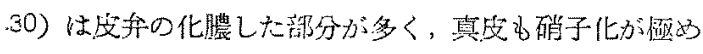
て高度である。

骨K損傷のあるもの 4 例 (No. 25, 28,34, 38) では， 骨小管闪に細胞浸潤があり，骨の充血を認めるものが1 例（No. 25）あつた。表皮が】翟であるすのは，皮弁の

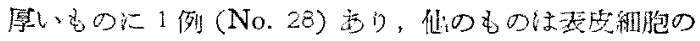
变性情需蔗でる部分が多い。

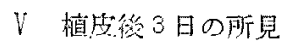

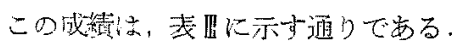

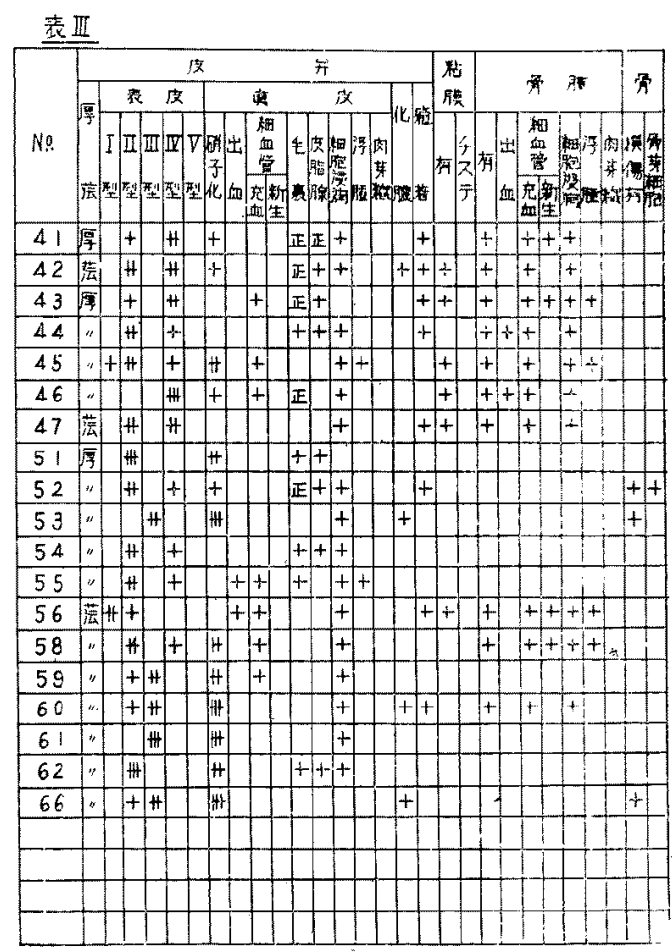

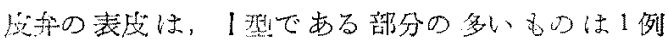

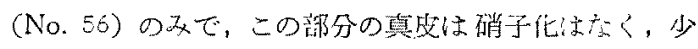

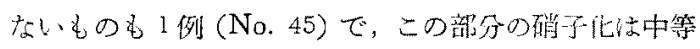

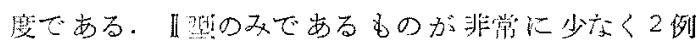

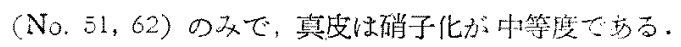

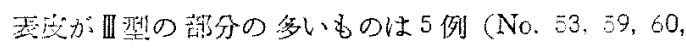

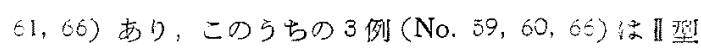

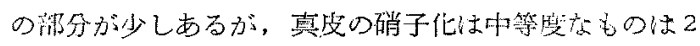
例 (No. 59, 61) で, 他の3例 (No. 53,60, 60) は硝

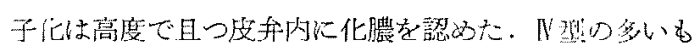

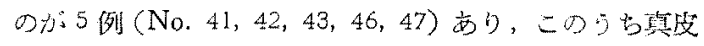

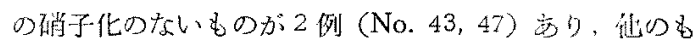

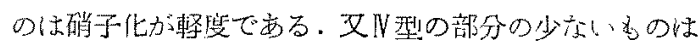

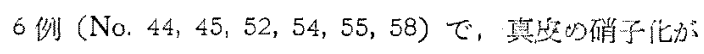

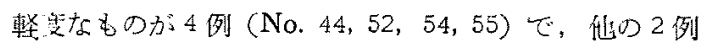
(No.45，58) は硝子化が性等度である。

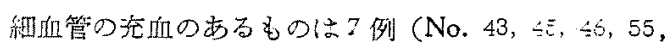




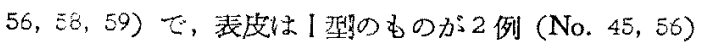

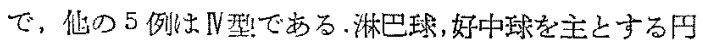
形細胞の浸琵が增版しているものが多く，細胞浸溜のな いものは3例（No，43，51，66) である。線維莱細胞の

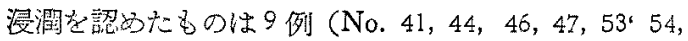

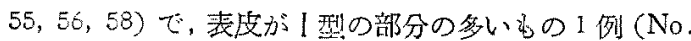

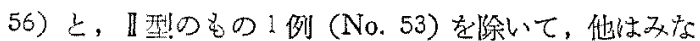

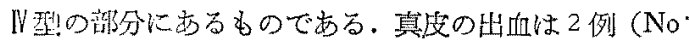

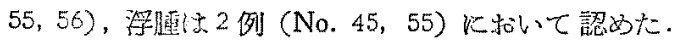

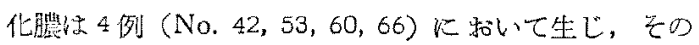
中の3 例(No，53,60，66) まで，表皮は型であり真皮

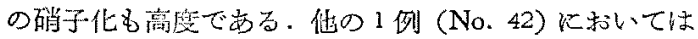

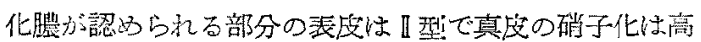
度であるぶ，他の部分では表皮はN型で真皮す碈子化ぶ 軽留である。

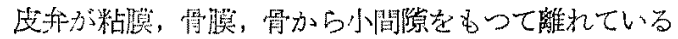

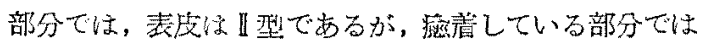

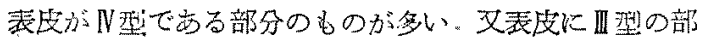

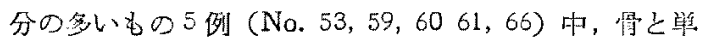

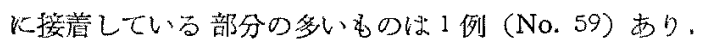
化の2列（No. 53，66) は，背との間に淋巴球，好中 球，好酸球定主とした細胞浸潤があり化㩨が括る。

彩成其のるもの6例 (No. 42, 43, 45, 46, 47, 56)

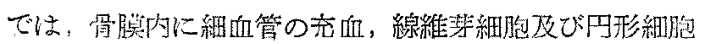
の搌椡が琶められ，細血管の新生のあるるの（No.43， 56)当ある。糊膜上皮が湝尖している部分のあるむの

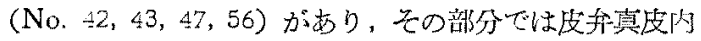

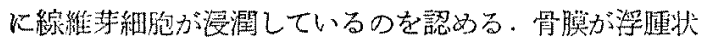

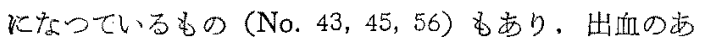

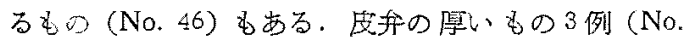
43，45，46）ては表皮はN型の部分加市り，皮弁の薄、

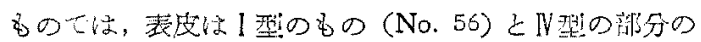
あるすの（No. 42，47）とがある。

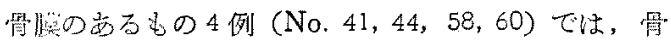

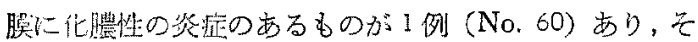

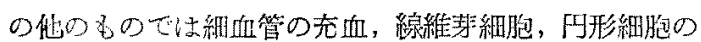

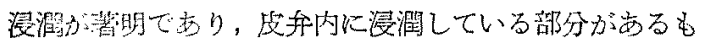

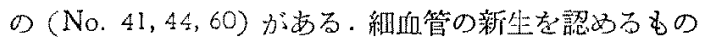

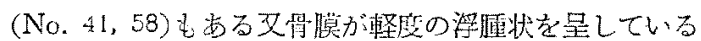

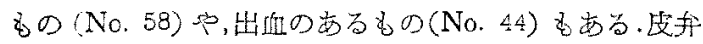

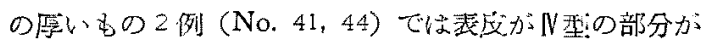

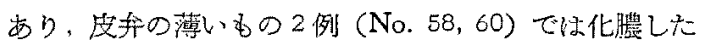

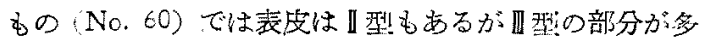

く，他のむの (No. 58) では，IV型の部分がある。

骨飞提稘のない子の6例 (No. 51，54，55，59，61，62)

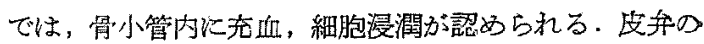

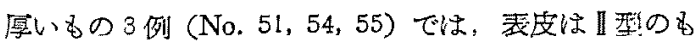
の (No. 51) 及びN型の 部分のある而の (No. 54, 55)

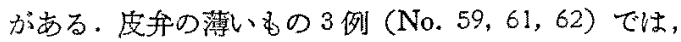

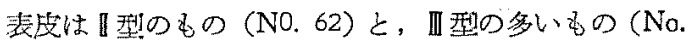
59 ，61）加市り，1例（No. 59）は骨面に多くの部分加

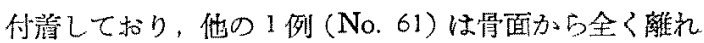
ている.

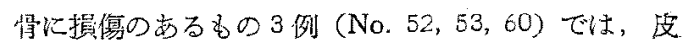
我の厚い, 02 例 (No. 52,53) の5ち，1例 (No. 53)

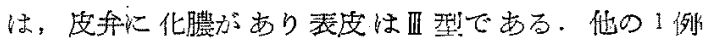

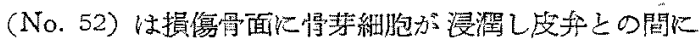

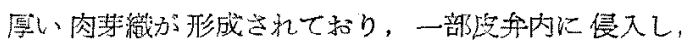

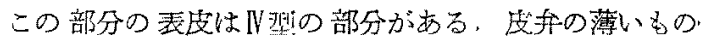

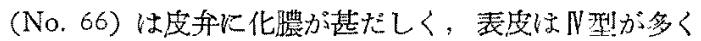
颠皮の硝子化む高度である。

11 植皮傒5日の所罢

この成縜は，表N以示す通りでする。

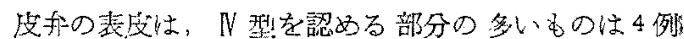
囊

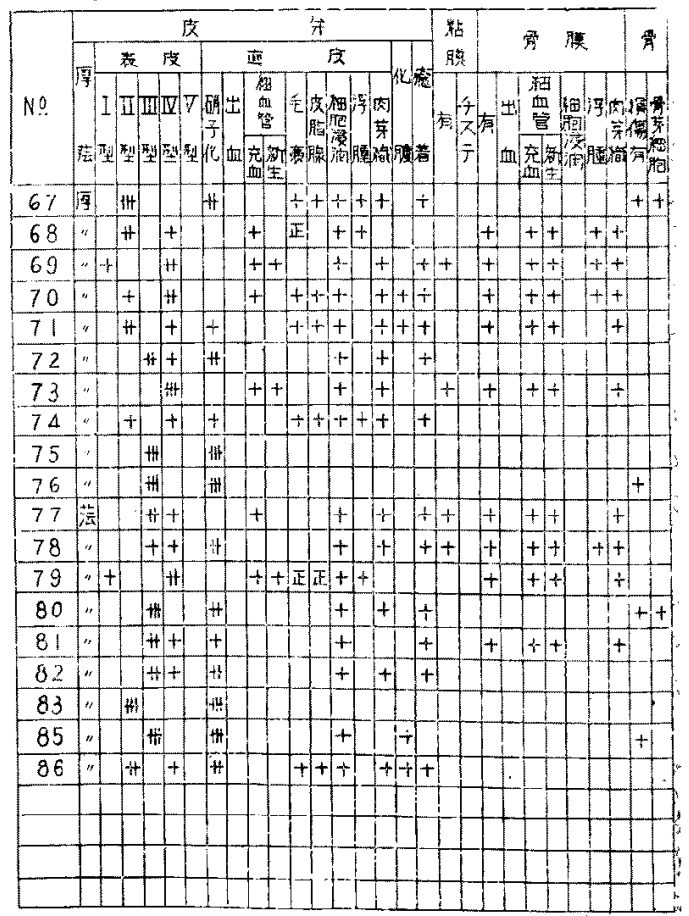


(No. 69,70，73，79) で，この部分の真度には硝子化を

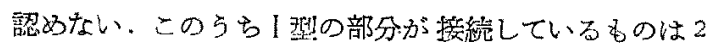
例（No. 69，79）あり，この部分の真度む林硝子化を 認めない，他の 1 侧（No. 70）では，II型の部分が接綒 しておりこの部分の真皮には涤巴球，好酸球，好中球を 主とする細胞浸㧚が著明で化朖性焱泟があり硝子化も高

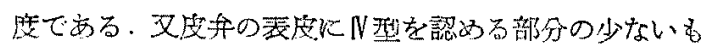
のは9 例 (No. $68,71,72,74,77,78,81,82,86$ ) で,

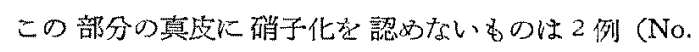
68,77 ) で，硝子化が軽度な子小は 3 例 (No. 71, 74, 81) で，他の 4 例 (No. 72，78，82，86) には硝子化か 中等度に認められる。しかしてこれらに】㑭の部分が挼 続しているものは 4 例 (No. 68,71，74，86) で，この 部分の真皮に硝子化が軽度なる。は 1 例 ( N 0.68$)$, 中 等度なもの1例 (No. 74)，他の 2 例 (No. 71, 86) 飞 括いては硝子化が高度で且つ艺の部分に化膆を認める。 文四型の部分が 揬絗しているものは 5 例 (No. 72，77， $78 ， 81 ， 82) て ゙ ＼mathrm{~ こ の 部 分 の 真 皮 の 硝 子 化 か ゙ 軽 度 な る ~}$ は2 例 (No. 77,81)，中等度な子のは1例 (No. 73)， 高度なものは2 例 (No. 72，82) である.以上の他，表 皮にN型の部分を認めないるのは6 例 (No. 67，75，76, $80 ， 83 ， 85$ ) で, I型の部分のみのものは2 例 (No. 67, 83)で，1例 (No. 67) は真皮の硝子化が中等度で，他 の1列 (No. 83) は碏子化が高度である. 又四型の部分 の双のもの4 4例 (No. 75, 76, 80, 85) で, この5ち 真皮の硝子化が中等度なる 1 例 (No. 80) で, 他の 3 例 (No. 75，76，85) は硝子化が高度で，この5ちの1 例（No. 85）は皮升の化膿が㯏だしい。

真皮内細血管の充血性6 例（No. 68，69，70，73，77， 79) に括いて双られ，細血管の新生は3 例 (No.69,73， 79）に認められ，いずれも主として表皮が倠である部 分が多く、真皮の硝子化のない部分飞おいてみとめられ る、線維莪細胞及び淋巴球，好中球主主とした円形細胞 の浸㵎は大部分のるのにみられるが，3例 (No，75，76， 83）に执いては認められず，これらの表皮はいずれる 四 型で真皮の硝子化る高度なるのである。肉莱織を認める 6のが12 例 (No. 67, 69, 70,71, 72, 73, 74, 77, 78, 80, 82, 86) あり, そのうちの3 例 (No. 70,78, 80) は

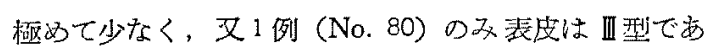
るが，他は凡て表皮は、型の部分である。真皮が倝度に 浮腫状を呈している。のは4例（No. 67，68，74，79）方 る、毛露，皮脂腺正常なるのああるが萎絔しているも のが多く，皮升の厚いものに多くみられる，

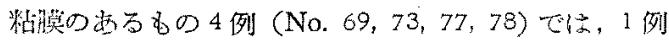

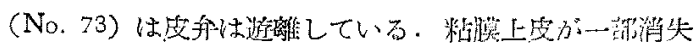

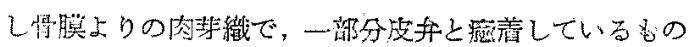

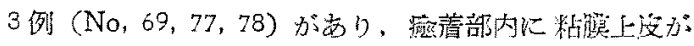
残䄈しているのを認められたが，大部分苦贲との間に細

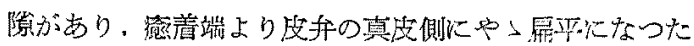

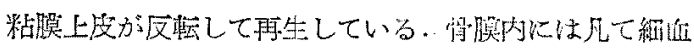

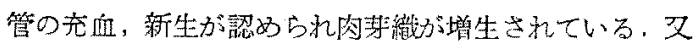

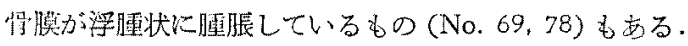

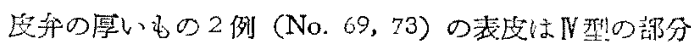

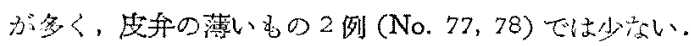

骨㬴のあるもの 5 例 (No. 68，70，71，79，81) では，

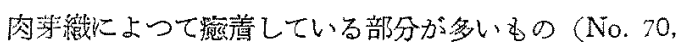
71，81）之。間隐をつて離れているもの (No，68，79)

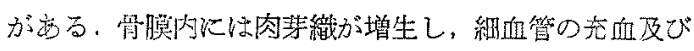

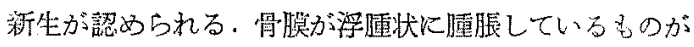
2 例 (No. 68，70) あり。艺の1例 (No.70) 沵骨膜の

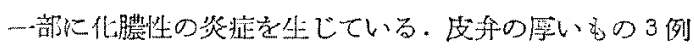

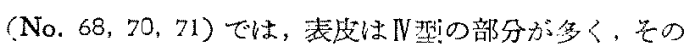

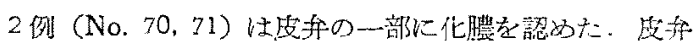
の薄いもの2例 (No. 79,81) では, 表皮はN型の部分 が多いもの (No. 79) と少ないもの (No. 81) がある.

骨炕損㰾のない子の6 例 (No. 72, 74, 75, 82, 83,86) では，情小管内に線維芽細胞，円形細胞が浸潤し，骨小

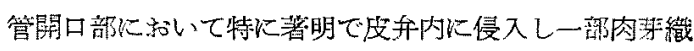
に上つて隐着しているすの（No. 72，74，82，86) があ

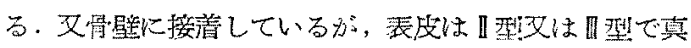
皮の硝子化が極めて高度なる（№.75，83）が方る。

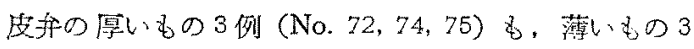
例（No.82，83，86）歹，表皮はN型の 部分は少ないる

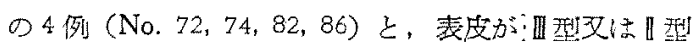
のみのもの(No. 75，83) とがある.波弁の薄い, 当ので 一部に化膿のあるものが1例（No. 86）あつた。

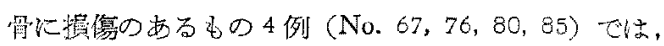

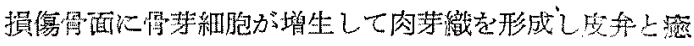

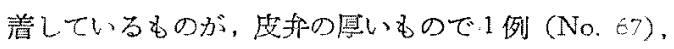
薄いもので 1 例 (No. 80) ある. 皮弁の厚い, ( No. 67，76）では，表皮が开型のもの（No. 67）と，四型の もの（No. 76）脑り，四型のbのでは真友の碍于化が

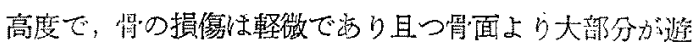
嵟している. 皮弁の薄いもの（No. 80，85）では，垡皮

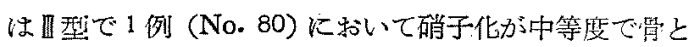
は肉茅織により一部㗪着しているが，他のるの (No. 85) 
では真皮の硝子化も極めて高度で且つ皮弁及びその周囲

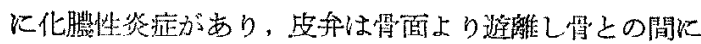

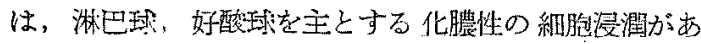
り，感の充侐力強い

VI 植皮後8日の所見

この成綕泣，表りに示寸通りである。

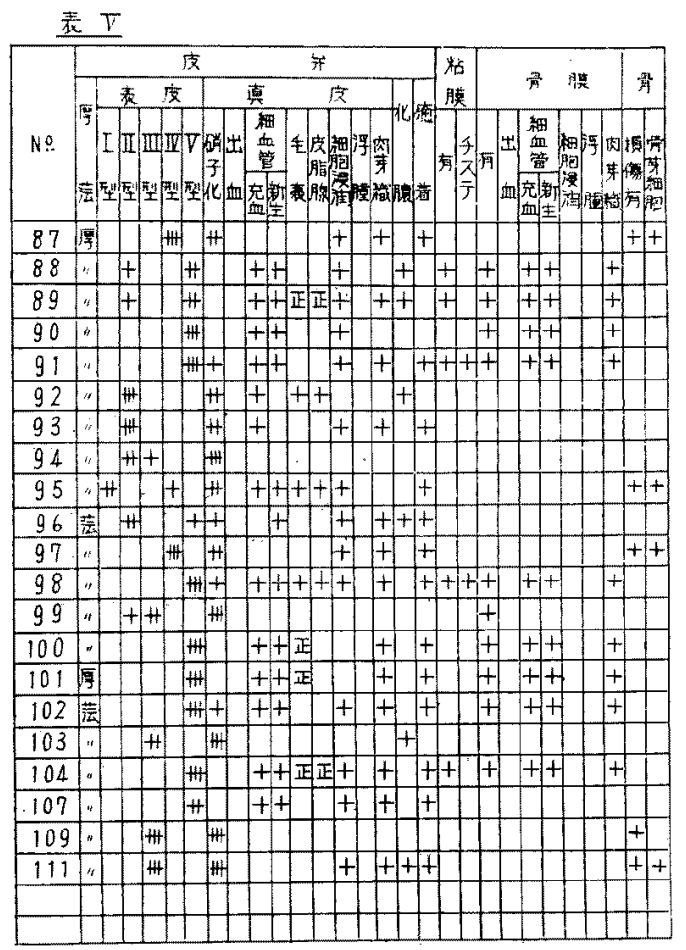

皮去の表皮蛙，V型の部分の 多いものが10例（No. $88,89,90,91,98,100,101,102,104,107)$ 击子。 こ の部分の真皮に硝子化を認的广い女のは7 例 (No.88， $89,90,100,101,104,107)$ で, この5ち 1 例 (No. 100) は肉韯絊で置き換えられている，又細血管の充血及び新

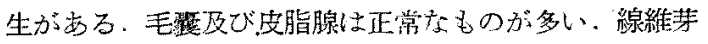
紐胞及び円形細胞の漫潤のあるもの（No. 88，89，90，

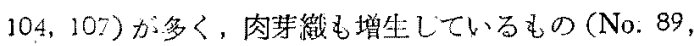
$100,101,104,107)$ が多いこの部分に接続して、型 の部分の称るものが2例（No. 88，89）场り，いずれる II 型の部分の真皮は化膿があり硝子化も中等度から高度 である、V翌の部分の真皮に硝子化が軽度に認められる ものは3例 (No. 91，98，102)で，いず扢毛細血管の充 血, 新生があり，線維帮細胞及び円形細胞の漫潤があり 肉帮秘も增生さ机ている、V型の部分の少ないものは1
例（No．96）で，真洪は硝子化が軽度で，細血管の新生

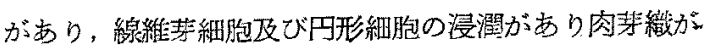
增生されV型の部分に接䋨して【型の部分があり，硝子 化が軽度で軽侵の化膿を認める、V型の部分のあるるの が3例（No．87，95，97) あり，この部分の真皮注硝子 化が中等度で細血管の充血及び新生は1例 (No. 95) に みられ，線維芽細胞及び円形細胞の浸澗忹了例共にあ。

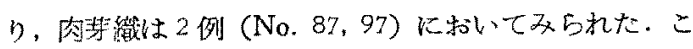
の部分にI型:の部分が接統しているのが1例 (No. 95) あり、このI型の部分の真发はN型の部分の所見と同様 である、】型の部分のみむるるのは3例 (Nc. 92，93， 94) で，このうち真皮侸硝子化が中等度にあるものは2 例（No. 92，93）で細血管の充血があり，1 例 (No. 92) は化澧があり，毛垔皮脂腺の薮縮がある. 線維等細胞 及び円形細胞の浸閵があり肉芽織を認めるるのが 1 例 (No. 93) ある. 任の 1 例 (No. 94) 恃真苫の硝子化が. 高度である、而型の部分の多いものは 4 例 (No．99， 103，109，111）でいすれ子真发の硝子化は高度である。 1 例（No.99）、、【型少少部分あり，この【型の部分 の真段は同様に硝子化が高度である.艮升の一部に化 膿を認めたものは2例 (No. 103，111)で，ちち1例 (No. 111) は化膿のない部分湶維茅細胞及び円形細胞

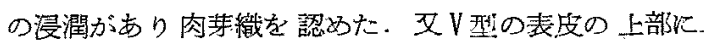
【型の表皮が菱縮した脂腺と共に剥離しているもの (No. 98) がある.

粘膜のあるるの 5 例 (No. 88，89，91，98，104) では..

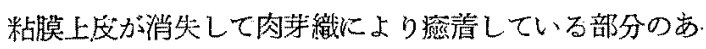
るむの（No. 91，98，104）もあり，この症着部內には粘

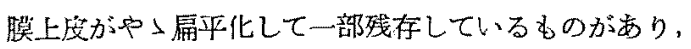
チステを形成しているもの (No. 91，98) もある.この チステの队腔は1〜2圈の円柱上皮からなつている，痖 着がなくて，粘膜面より皮弁が遊襍しているもの(No.

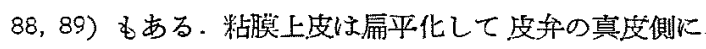
再生している，骨膜内には細血管の充血及び新生があ。 り，肉芽織が增生されている、1 例 (No. 88) において は，粘膜及び骨膜の一部分に化膿珄の炎症を認め，この

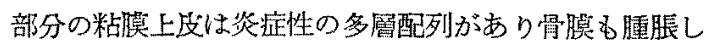
ている. 皮弁の厚いるの 3 例 (No. 88, 89, 91) む，薄 いもの 2 例 (No. 98, 104) も表皮はV型である.

骨膜のあるもの5 例 (No. 90, 99，100，101，102) で は，4例（No，90，100，101，102） は細血管の充血及び

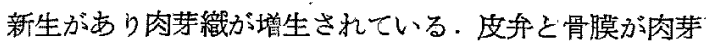

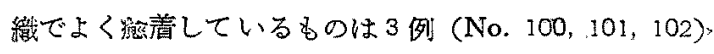




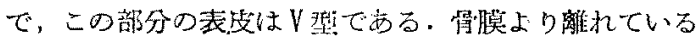
あのが1例（No．90）あるがこの部分の表皮はV型であ る.他の1例（No. 99）の骴膜は土才ジンに赤䧱して菲

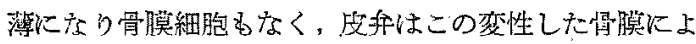

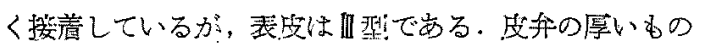
2 例（No，90，101）は，表技はV型で，薄いもの3例 (No. 99，100，102) む同棁 V留であるが，1例 (No. 99)

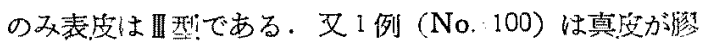

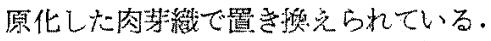

骨に損傷のない多の6例（No. 92，93，94，96，103， 107）では揨に充血があり，骨小管内に線䊒获細胞及び

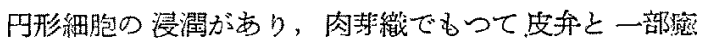
站しているすのが 3 例 (No.93，96，107）あり，1例 （No. 93）は，皮弁は厚いもので表发は片型で，他の 2 例 (No. 96, 107) は，皮弁は薄いむので表皮はV型で

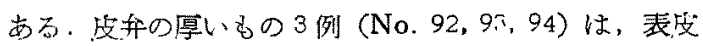

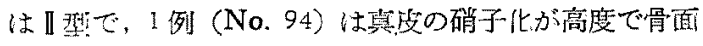

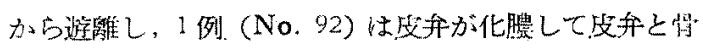
との間には化澧性の細胞浸潤がある，皮弁の薄いるの3 例 (No. 95，103，107）では，表皮は、型で骨と肉莱織

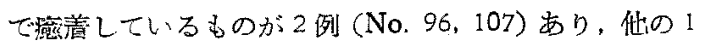

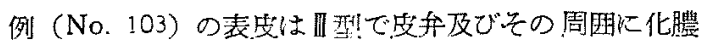
があり真段の硝子化む高度である。

情に損賃のあるもの 5 例 (No.87，95，97，109，111）

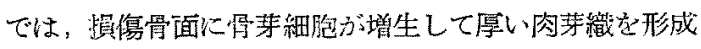

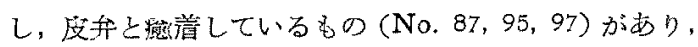

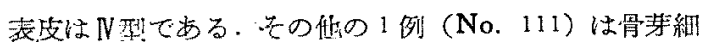

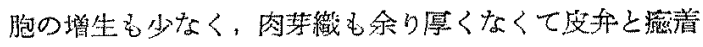

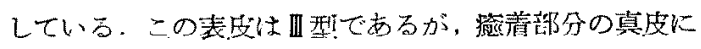
は硝子化は認好られず，化の部分では化膿性の炎症があ つて真皮の硝子化が高度である，又优の 1 例 (No. 109)

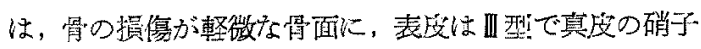
化も極的て高度な度弁が接着している。皮弁の厚いるの 2例（No．87，95）では，韯受はN羿であり，皮弁の薄

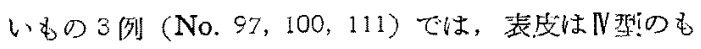
の (No. 97) と, 四型のもの(No. 109, 111) とがあ る.

\section{IIII植波啋 15 日の所見}

この成續は，表りに示す通りである。

皮強の表皮は，V型であるものが多く17 例(No.113， $114,115,116,117,118,119,120,121,122,123$, $124,125 ， 126,130,131 １ 32 ）$ 㐫る。この部分の真皮に 硝子化を認为ないものは13例（No. 113，114，115，

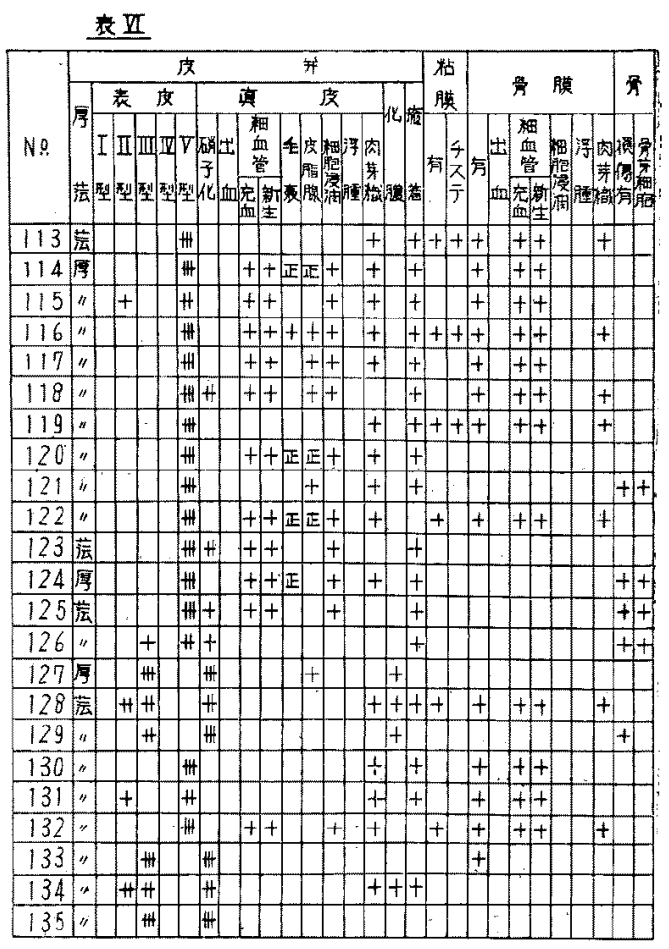

$116,117,119,120,121,122,124,130.131,132)$, 硝子 化が軽度なものは2 例 (No. 125, 126)，中等度なるの， は2 例（No.118，123）である.これらには細血管の充 血及び新生があり，線維孝細胞，円形細胞の浸潤のある むの (No. 114, 115, 116, 117, 118, 120, 122, 123,124, 125，132）が多い，页皮弁が粘償より遊離して在手内に 肉泺織が塻かにみとめられるもの2例 (No. 122，132)

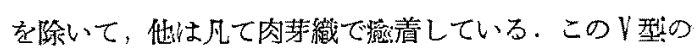
部分に，西型の部分が接繶しているものが2例 (No. $115,131)$, III型のものが1例（No. 126）あり、】型の

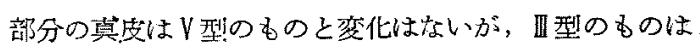
真皮の硝子化が㥛めて高度である、【型の部分と型の 部分上が共にあるものが2例（No. 128，134）あり，I

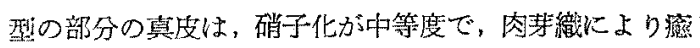
着しているが四梨の部分では，真没に化膿があり硝子化 も㯪るて高度である．この他に表皮の変性が高度で而型 のものが 4 例 (No. 127, 129, 133，135) あり. 真皮の 硙子化标極めて高度で，その中の2 例 (No. 127，129) は皮弁に化膿があり，1 例 (No. 133) はエォデンに赤 染して骨膜細胞を認めない菲薄な層によく接着してい る.他の1例 (No. 135) は骨膜がなく損傷のない骨面 
に上く接着している，毛整及び皮脂腺は正常なものむむ るが萎縮高度なものむあり，変性になつた既存表皮と共 に剥離しているもの (No. 116, 123) 主認めた。

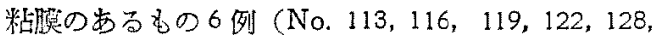
132）では，粈膜上皮が消失して皮弁と淕着しているも のが 4 例（No. 113，116，119，128）西るが，菠弁之の

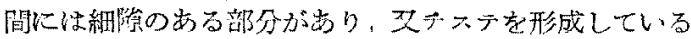
もの (No. 113，116，119) もある.このテステの内壁は

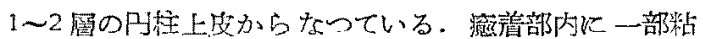
膜上皮が残存しているものもあり，この上皮性扇平化し ているものもある．皮升怗粘獏面上り遊離しているもの （No. 122，132）がある。骨膰内に性細血管の充血及び 新生があり，肉芽繶が增生されている，粘膜及び骨膜の 一部分に化膿を認めたもの(No. 128)もありこの部分の

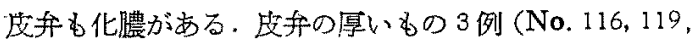
122）は表皮はV型であり，段弁の藻いもの3 例 (No.

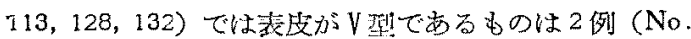

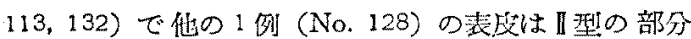

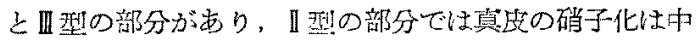

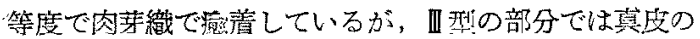

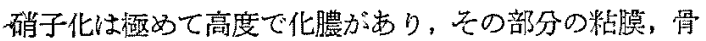
"膛にも化膿が認められる。

骨营のあるもの 7 例 (No. 114, 115, 117，118，130， 131，133）では，細血管の充血及び新生があり，因第織

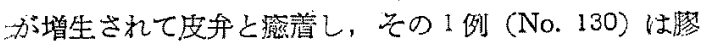
原化した肉苏織で具皮は置き換兄られているが，1例 (No. 133) のみは，骨膜は五オデンに赤染して菲薄化し 骨膜細胞も認められてい，しかしてこれに型真皮の硝

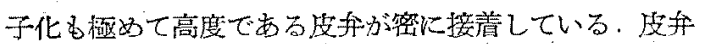
の厚いもの 4例（No１14，115，117，118）では表皮は V型である. 皮弁の薄いもの3 例 (No. 130，131，133） では，2例（No.130，131）は，表皮がV型であるが， 他の 1 例 (No. 133) は开型である。

骨に損傷のない子の 5 例（No. 120，123，127，134，

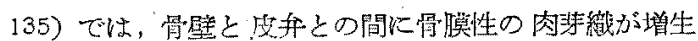

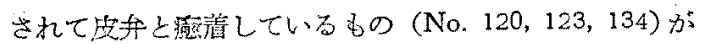

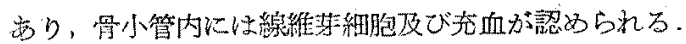

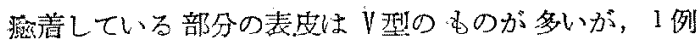

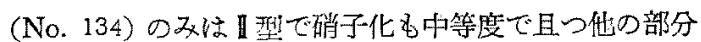
化化澧があり，この部分の裴皮は亚型である，皮弁の厚 いもの2例（No，120，127) は，1 甽 (No. 120) がV 型で他の1例（No，127）は四型である. 皮弁の薄いも 的3 例 (No. 123, 134, 135) では, 1例 (No. 135) 忙
回型であり，他の1例（No. 134）は表皮が型心部分 と四型の部分施古り，四型の部分の真皮には化膿がある。

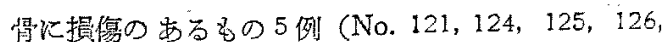
129）では，骨に充血があり，損鹪骴面には多数の常帮

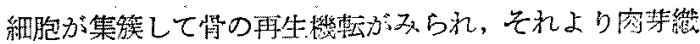

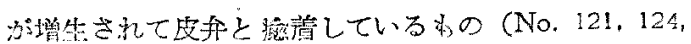
125，126）がむり，これらの糡皮はV刑である。

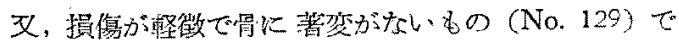

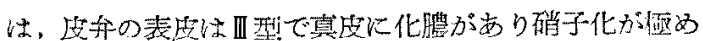
て高度であり，骨とはよく接着している。选台の军いも の2例（No，121，124）は，表度はV型で港着があり，

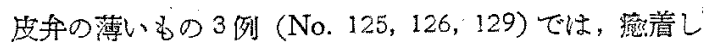
ているもの（No. 125，126）沐，表质怯型で西るが;

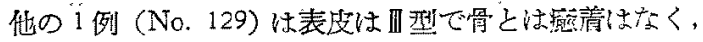
たざ接着しているのみであり化膿している部分が篟か次 西石。

IX 植皮後30日の所見

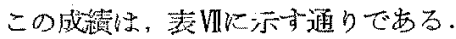

皮昪の表专は，V型の部分のものが 12 例（No. 145， $147,148,149,150,151,154,155,157,158,159,160)$ あり，真皮は硝守化のないるの (No. 145, 150, 151 . 表江

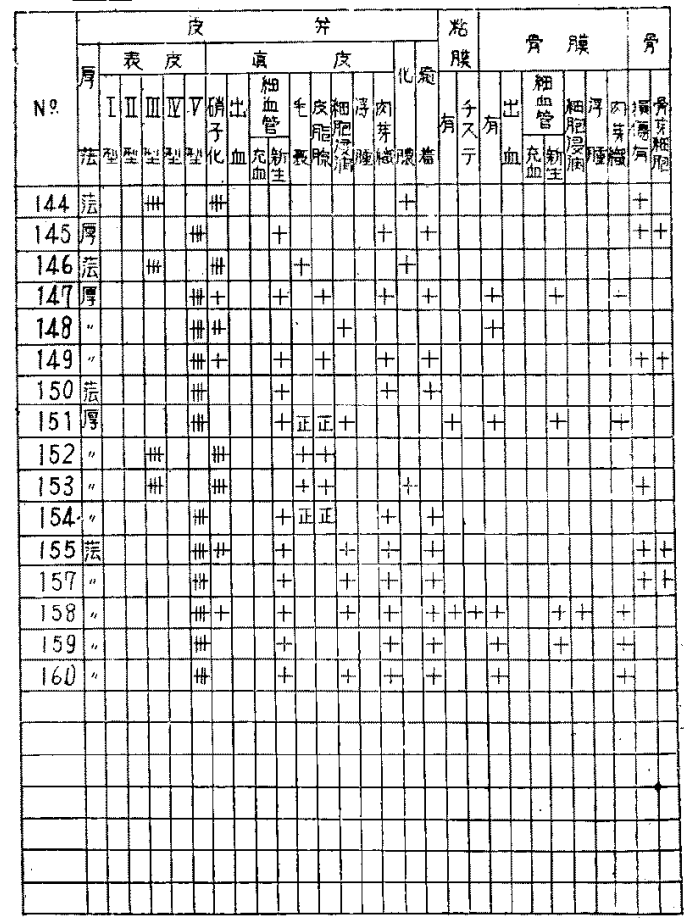


154，160), 硝子化の 軽度な 6の (No. 147, 149, 158) 硝子化の中等度なもの（No.148，155) 及び線維性の肉 苏織で置き换えられているもの（No. 157，159）とがあ

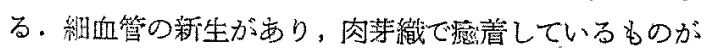

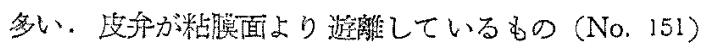

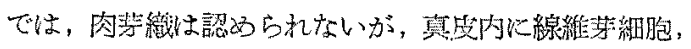
円形細胞の浸濯がある。骨膘面上り遊離しているもの

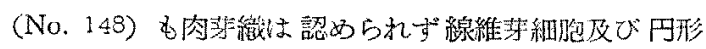

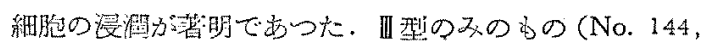
146，152，153) では, 真发の硝子化も極めて高度であ

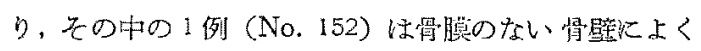

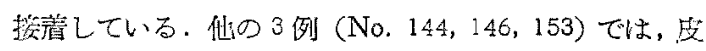
手は化澧している，毛翼及び没脂腺は正党なるのもある

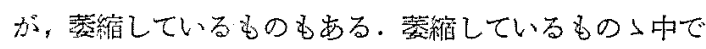
空胞化しているもの（No，147）るあつた，敖皮の乳頍 の発老は良くない歹のが多いが，時に良好なものむる。

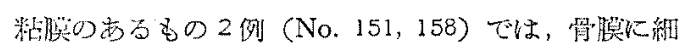

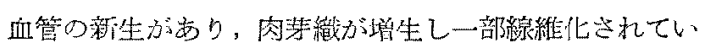

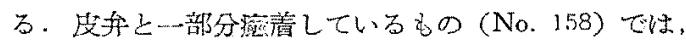

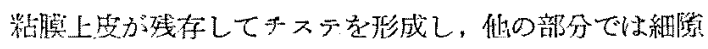

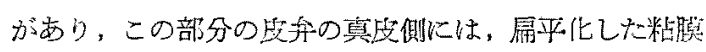

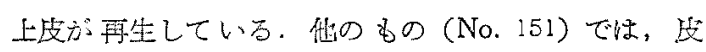

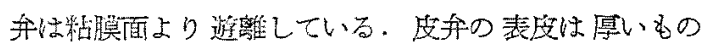

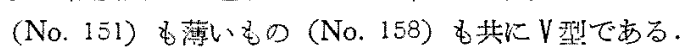

学膜のあるもの4侧 (No. 147.148, 159,160) では,

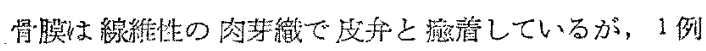

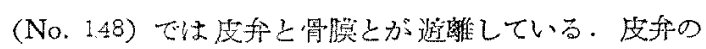

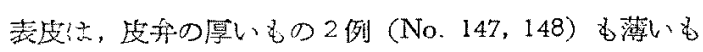
の2例（No. 159，160）共にV型である.

骨に損甥のないもの4例 (No. 146, 150, 152, 154) て

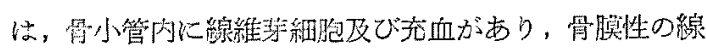

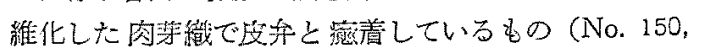

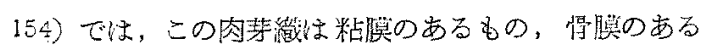

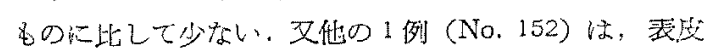

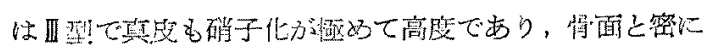

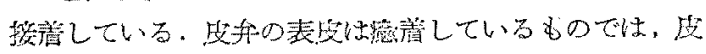

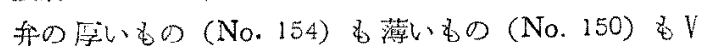

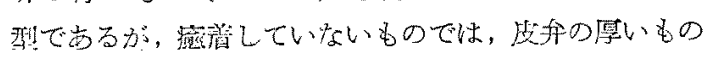

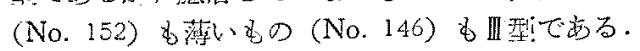

骨に損傷のあるもの6例（No. 144，145，149，153，

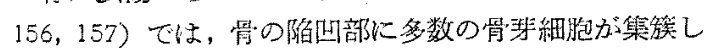
て管の充血があり，骨の再生機枟を認好，皮弁は得膜 と連続与る陳旧な肉第織を形成して痖崖しているもの
(No. 145，149，155，157) がある。これらのもの>表版

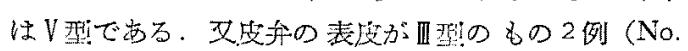
144，153）では传括化化澧があり，骨との間にも化澧性

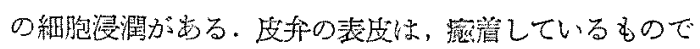

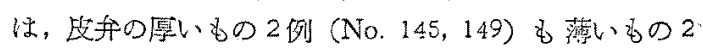

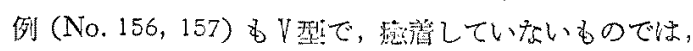

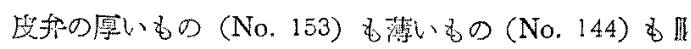

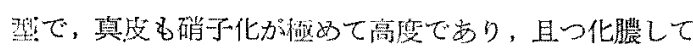
いる。

\section{第 4 章 総括並に考按}

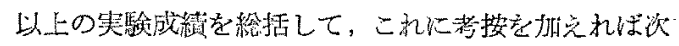
の上うである，段弁の表发は，移䅦後1日の16例打 いてI型の部分の多い电のは5例 (No. 1, 2,3.8, 16), 少ないものは4例 (No. 6，9，10，15)で，他の7例は

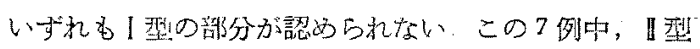
の部分の多いものが5例（No. 4, 5, 7 13，14）で佂の.

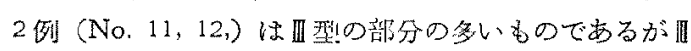

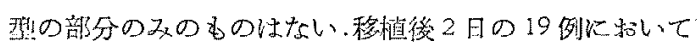
は，I㥜の部分の多い6の性4 例 (No. 18，19，20，26)， 少ないものは3例 (No.17,21,27) で, 他の12例はい ずれもI型の部分が認めら礼ないこの12例中，【型 の部分の多いものは 5 例 (No. 22，23，28，31，32) で， 化の 7 例 (No 24, 25,29,30,33,34,38) は 四型の部。 分が多く、この中の3例(No. 24,30，34）江四型の部，

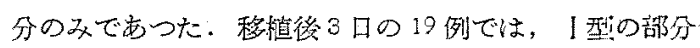
があつてN型のないいの优 1 例 (No. 56) のみである.

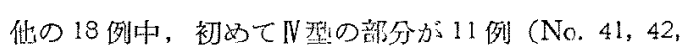
$43,44,45,46,47,52,54,55,58)$ K机儿恐好机 た。残りの7例中，回望の部分の不の乎のが 2 例 (No.

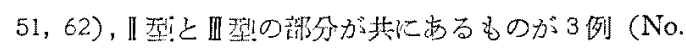

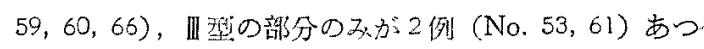
た、植段後 5 日の19例では，N型の部分のあるものが 13 例尚り，このN型の部分が多いものは6例 (No. 69, $70,73,74,78,79$ ), 少拟当のは 7 例 (No. 68, 71,

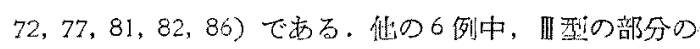
又のものは4 例 (No. 75, 76, 80, 85) で残りの2例

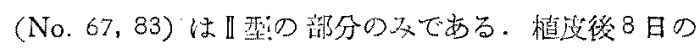
21 例では, N型の部分のあるもの㤡 (No. 87, 95， 97)，II型の部分のあるものが 3 例（No. 92，93，96)，

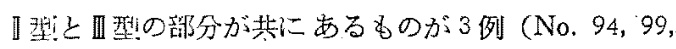
103)，四型の都分のみの多のが 2 例(No. 109，111)で残 nの 10 例中 (No. 88, 89, 90, 9198,100, 101, 102, 104,

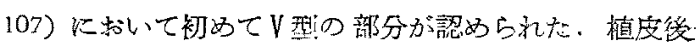


15日の 23 例ては，V些の部分のあるむのが17 例 (No。 $113,114,115,116,117,118,119,120,121,122,123$, $124,125,126,130,131,132)$ で护常に多く, 残り6例

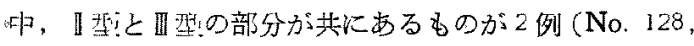

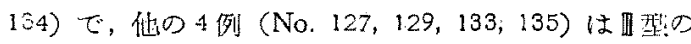

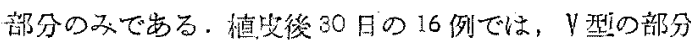

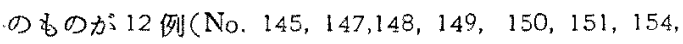
$155,157,158,159,160$ ) で残りの4 例 (No. 144, 146, 152，153）は㨫部分のみであつた。

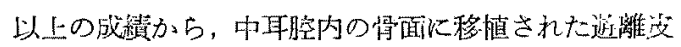

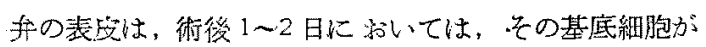
よく保持されている部分のある女のもあるが，退行变性

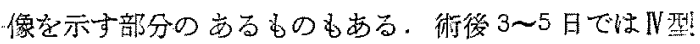
の喵分のあるものが多くなつているが，このN琶の表皮 。(付図9，10）は，一力正常な表段細胞の変性の移行像之

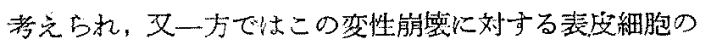
丽生の像と考えられる。特に付区18，22k双る上5に，

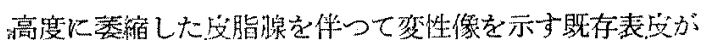

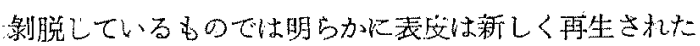
ものである。しかして術後8日以後では，V翟即ら表占 細胞は盵厚（付圂 18〜28）している，即古皮弁は，初 わ退行変性を示与吕3〜5日後に新しく再生され, 以

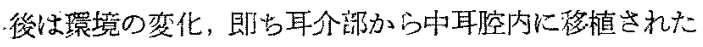

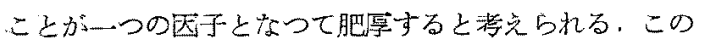

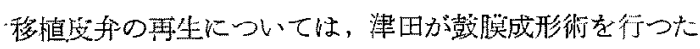

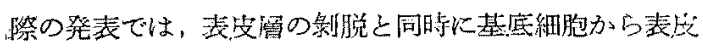
殿の画生が行和れると述べている。

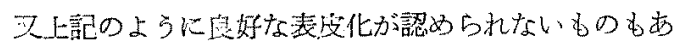

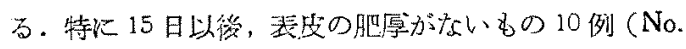
$127,128,129,133,134,135,144,146,152,153)$ KD

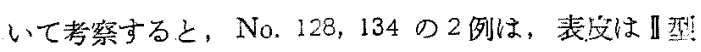

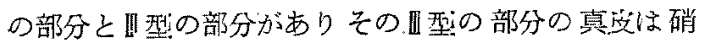

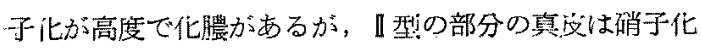

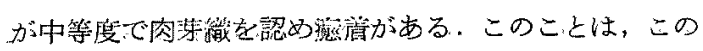

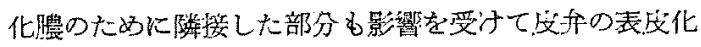

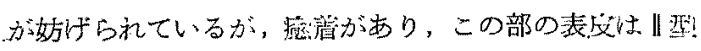

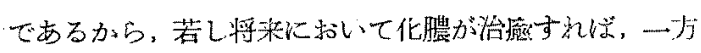

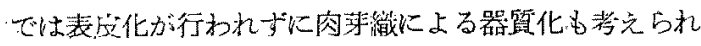

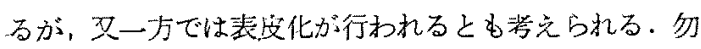
論成全全部に化脿が波及寸れば表度化は行われないであ ろらが，いずれにしてもこの2例はその後の裔策化不良 とは、断定できない，次に No. 127，129,144,146,153 の5例は，いず扎も表皮は四唯のみで真皮の硝子化は楆

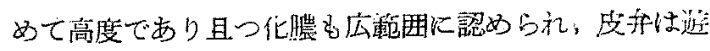

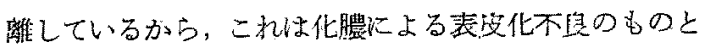

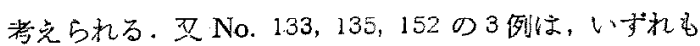

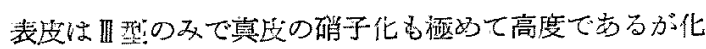

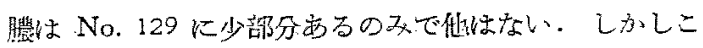

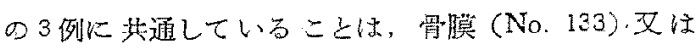
捎面に密に接している部分が多いことである。ことに

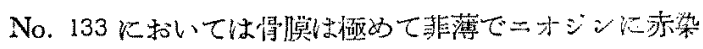
し且っ㥂䐳細胞を珰めないことにより，恐らくは移䐈後

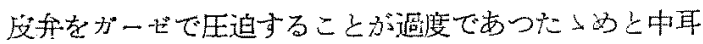

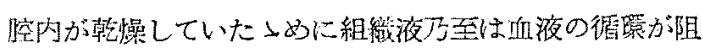

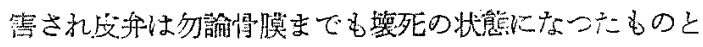

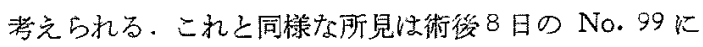

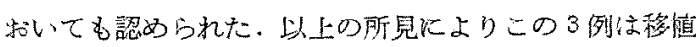

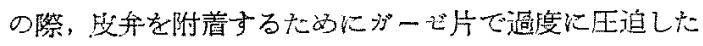

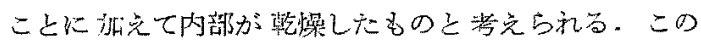

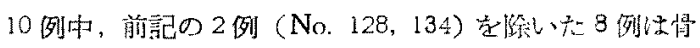

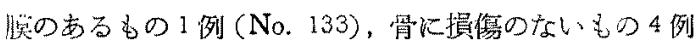

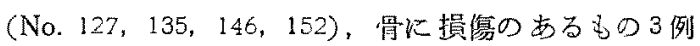
(No. 129，144，153) である. 更に移植後8日の子の21

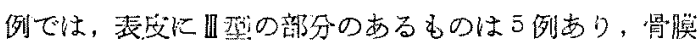
のあ万舟の1例 (No. 99) については前述の通りであ る.骨に撌稘のないすの2 例 (No. 94, 103) の5b

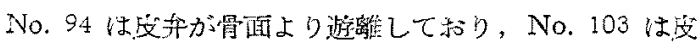

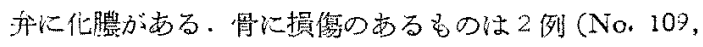

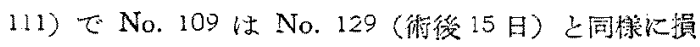

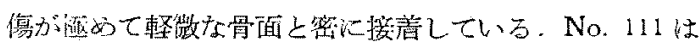

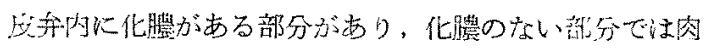

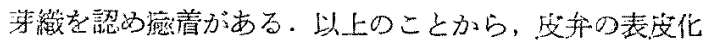

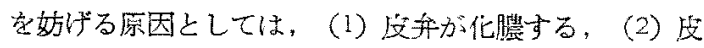

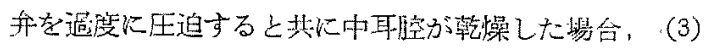

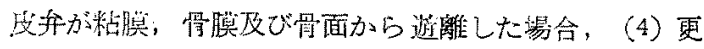
に骨壁の状態しして，骨膜のない場合が考劣られる。

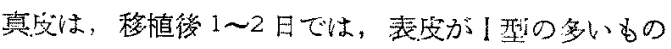

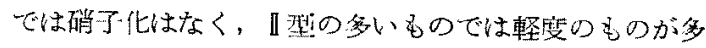

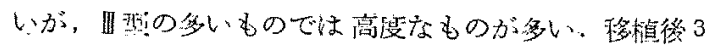

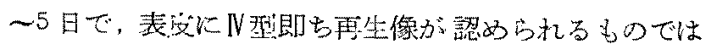
硝于化はない力整安のものが多い，移㯕 8 日以後て

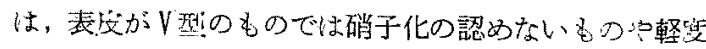

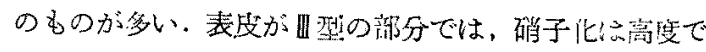
あり，その部分に化膿を認めるものが多い

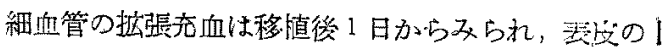
侸の部分に多く認められるが四堽の部分では認めらず, 
3〜5日では宸皮の輌生が行われている部分に多く，8日 以後では表皮が肥厚を示す部分に多く認めら机る。

多核白血球，淋巴球を主とする細胞漫潤心，移植後 2

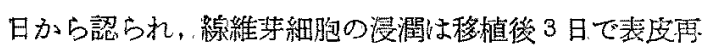
生のある部分に諰められる。移植後 5 日では情壁側より

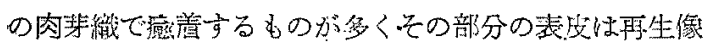

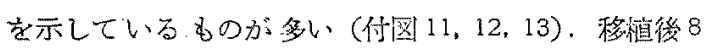

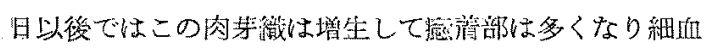

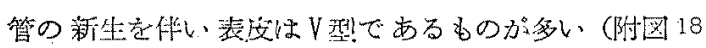

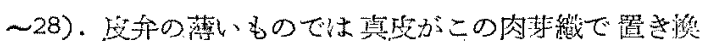
えられているものがある(付図 19，20，25，27).

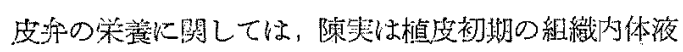

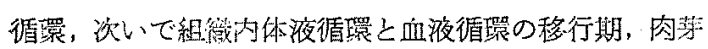
期の血液循環，乞して修復期の血液偱環の4期に分けて

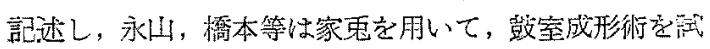

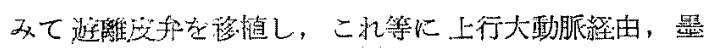

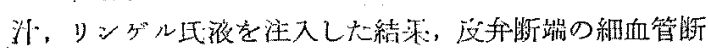

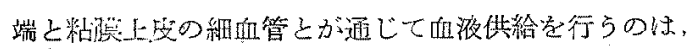

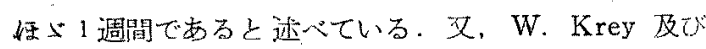

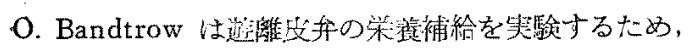

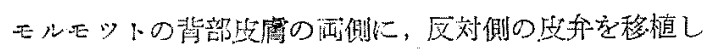

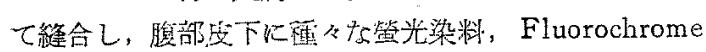
(Natri, Fluoreszine の 15\%年溶, Rhodamin B O 10\%卡溶液, Acridinorange 07.5〜 10\% 水溶液)を注

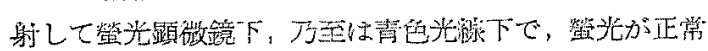

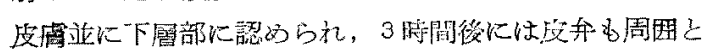

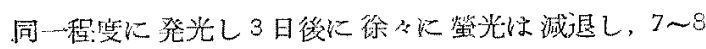

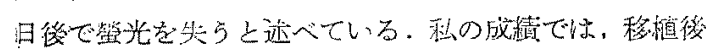

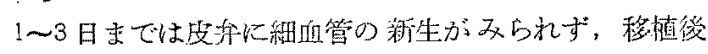

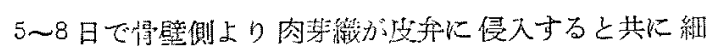

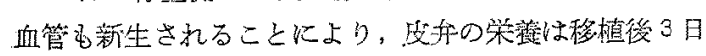
までは維減队体液により行われ，移植後 5〜8日で血液

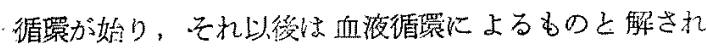
る.

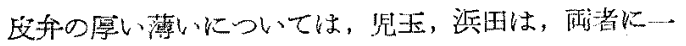

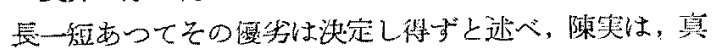

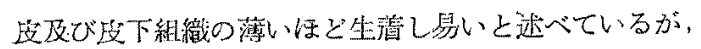

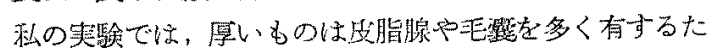

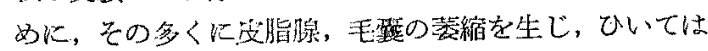

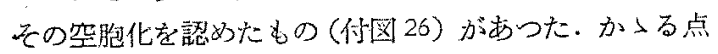

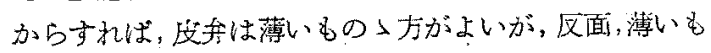
のは化腆性の炎症を生ずるものか愿いるのに比してゃ」 多かつた。この点に関しては，天野，因中（英) 毛既に

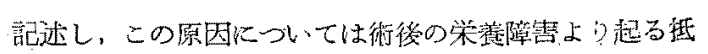

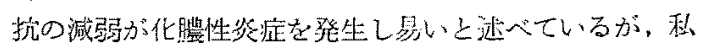

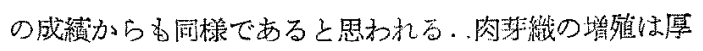

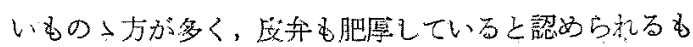

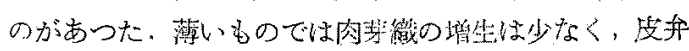

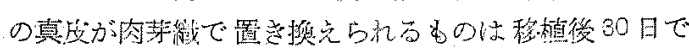

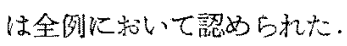

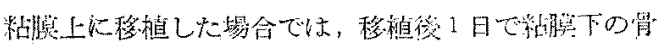

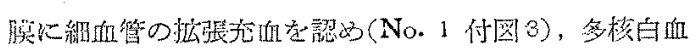

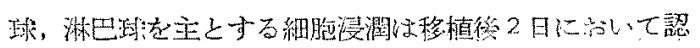

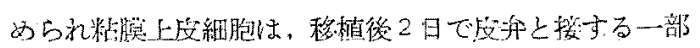

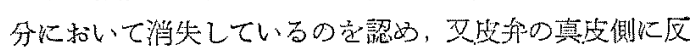

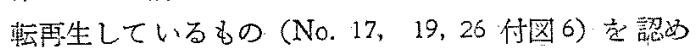

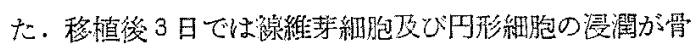

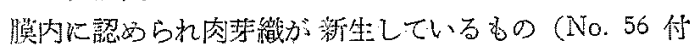

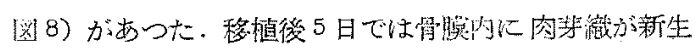

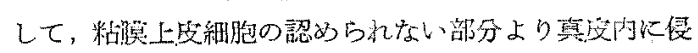

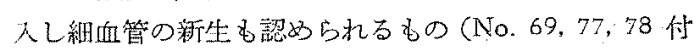

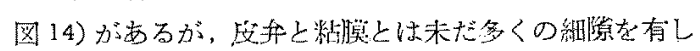

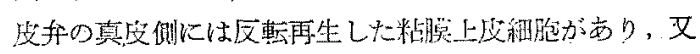

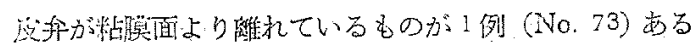

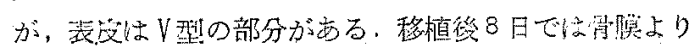

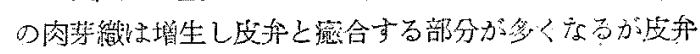

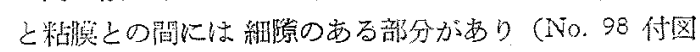

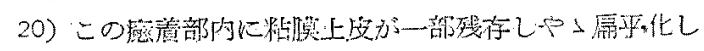

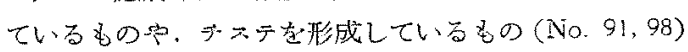

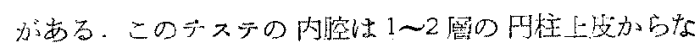

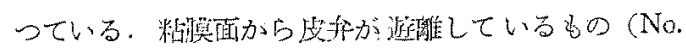

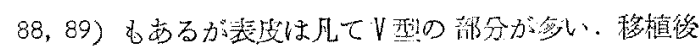

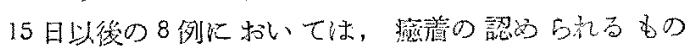

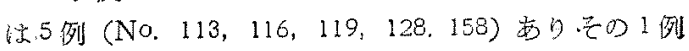

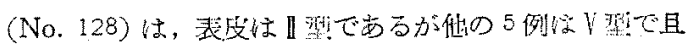
つテステを認めた（㤔图21，23）。しかして他の2例は

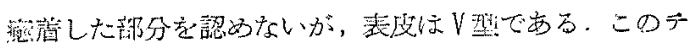
スラの成因については, 西端等は術捘, 残存した円柱上

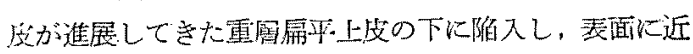

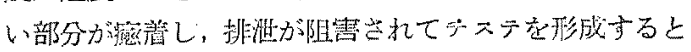

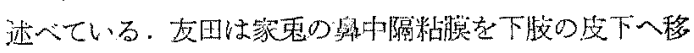
植するとテッテ穵形成し，丹柱上皮は扁平化すると述

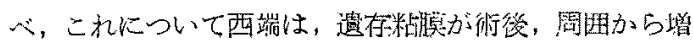

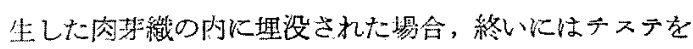

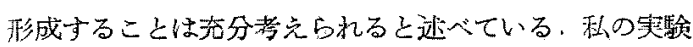

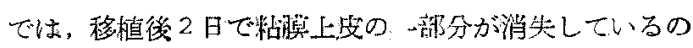




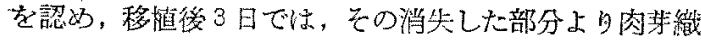

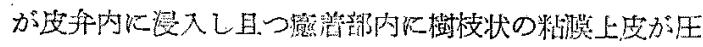
“迫され，中〉屚平化して残存しているもの（付图8）を

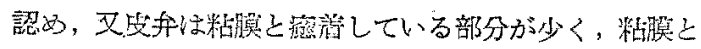

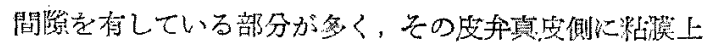
改が再生反転していることにより，かつる小さな䊀臊の

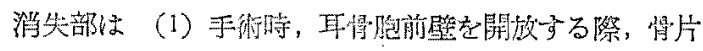

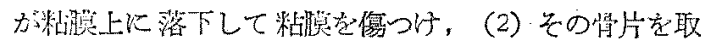

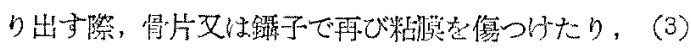

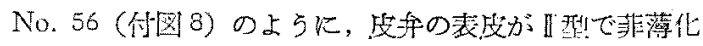

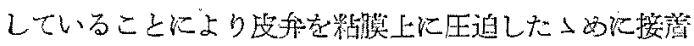

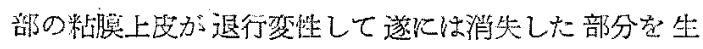
じ，(4)この他，度弁と粘償が，ずれて磨察孛生じ(3) と同嵄な経過で粘膘の消失部が生じ，そのしころ上り肉

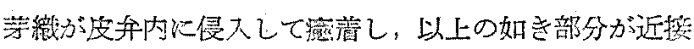

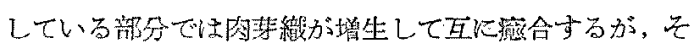

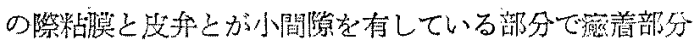
に閐塞されたものが一部は樹枝状に残存し一部はラステ になるのではないかと思考される. 又移植後 15 日以後

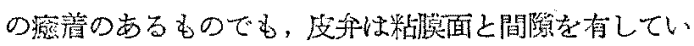
る部分があり，又表没はV型でも遊離しているものが 2

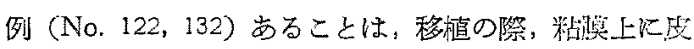
手它任迫することが不足であつたことす落えられるが，

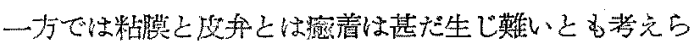

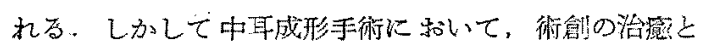
は，Mayer 等怔術創全面の完全な表皮化であると述べ， Grunert, Laurowitsch, Lange 等索始好とし; いす゚れ

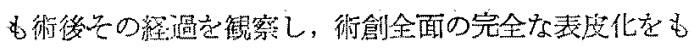

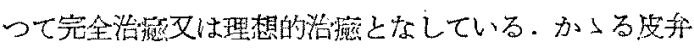

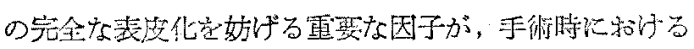

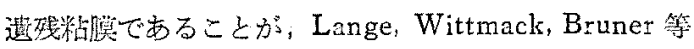

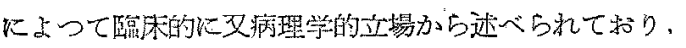

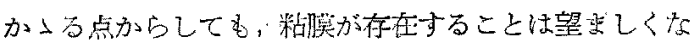
w.

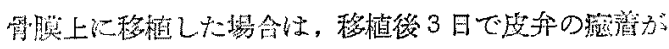

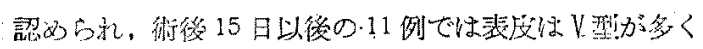

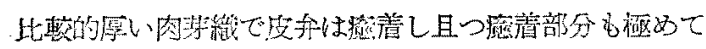
约いのが9 例 (No. 114, 115, 117, 118,120, 131, 147, 159,160 付圂 20，22，24，25) あり，仙の1例 (No. 148)

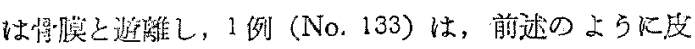
弁の压迫等により骨䑏と共に類塆死となつている。

骨膜がなく霄に損傷のない党面に移植した場合は，移

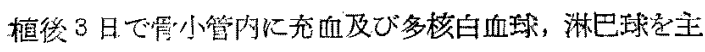

とする円形細胞の泿㵎が認められ，移植後5 日では，骨 小管内に線維莱細胞，円形細胞の增生があり，抒小管閶

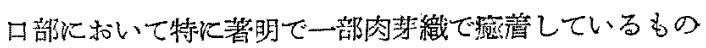
（No.72，74，82，86 付図 12）があるが，表皮注，I型

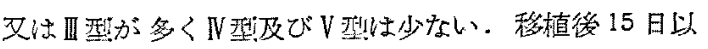
後のもの9例中，裁皮がV䍿のるのは4 例 (No. 120，

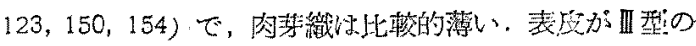
ものが5例放り，その中の3例 (No. 127, 134,146)は

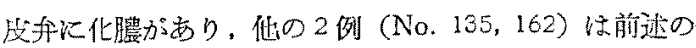
上らに段弁を逗度に圧迫したつるである。

骨に損傷を与克た場合は，移楒後 3 日で厚い肉第織を

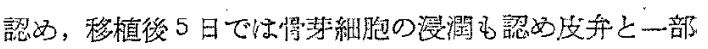
分窟着しているもの（No．67，80 付图 13）があるが，

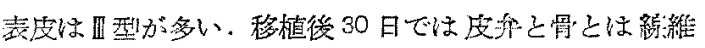

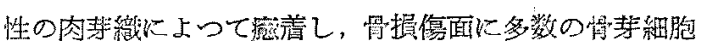

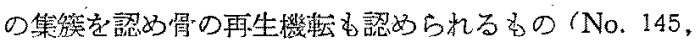
$149 ， 155,157$ 付図 27，28）があり表皮はV羿であるが， 未だ骨質の沈着は認められなかつた，高久は家區を使用

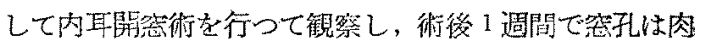

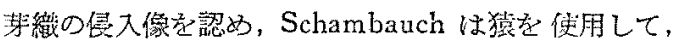

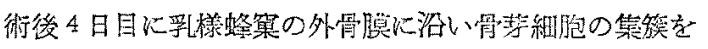

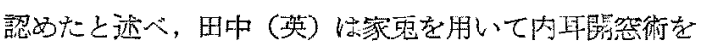

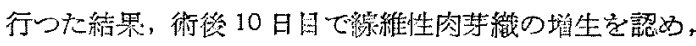

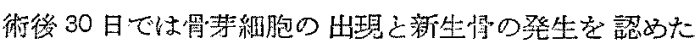

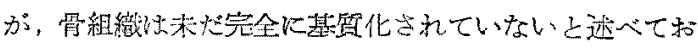

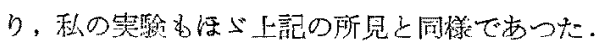

\section{第 5 章 結 論}

鼓室成形衍の基碟的研究の一環として, 成熟家鬼の， 正骨胞内に遊離友弁を移植した結果，次の如き知見を得 た。

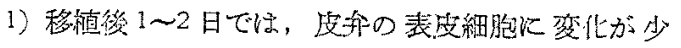
く，移植後3 5 日では，既存表支性变性像を示すが， 茢しくその下に表放が再生され，移植後8日では，既存

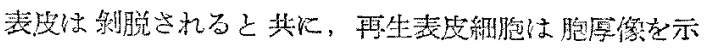
$\rightarrow$.

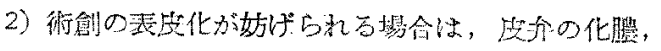

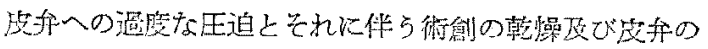
避離である。

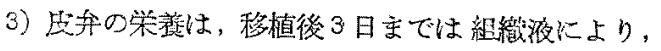
移植後 5 日立では一部組織内液一部血液循環に上り, 移 植後8日以後で恬血液循環により行われる。

4) 粘朕上に移植した場合は，ヂステを形成するもの が多く，且つ皮昪と粘膜は間隚を有している部分が多 
\&.

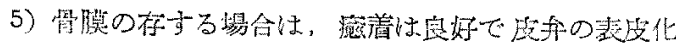

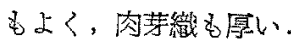

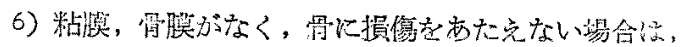

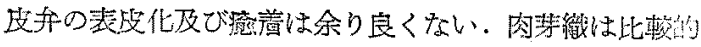
少ない。

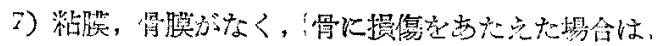

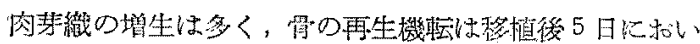

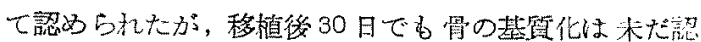
bhtsh.

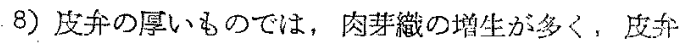

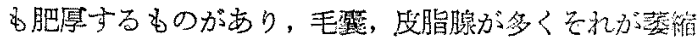
乙空胞化したるのるあらた。质升の薄いるのでは，肉芽

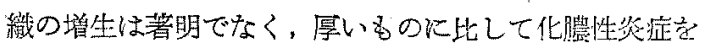
起す西の力゙や小多い。

\section{主 要 文 献}

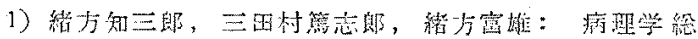

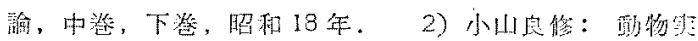

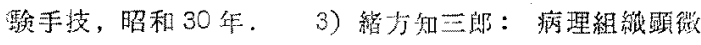

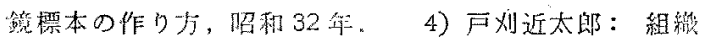

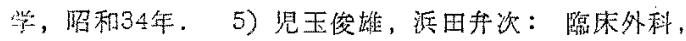

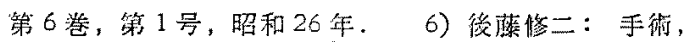
第 7 巻，第 10 号，7) 啳藤修二：日耳会，第 25 卷，

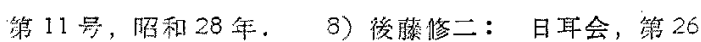

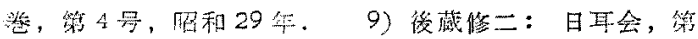

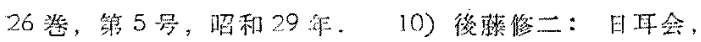

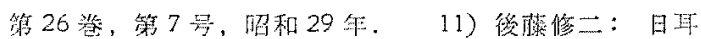

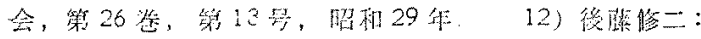

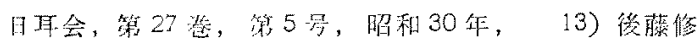

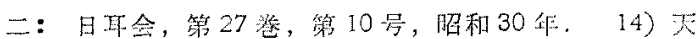

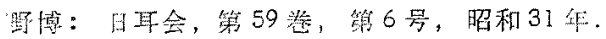

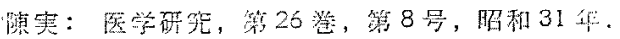

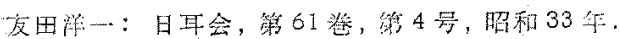

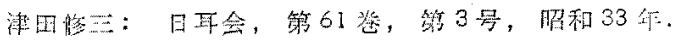

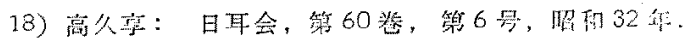

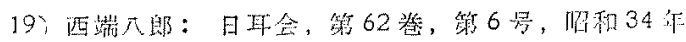

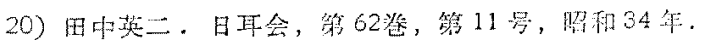

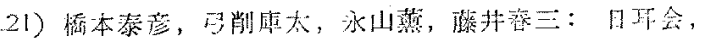

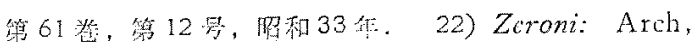
Ohr Heill 45, 1898. 23) Lange, W.: Beitr. Anot. Sc., Ohr. 3, 1910, 24) Schambaugh: Arch. Otolaryng. 41. 1935. 25) Lange. K.: Surgery. 15: 88. 1944. 26) Mir. Y. Mir.: Plast. Reconstr. Surg.
8: 378, 1951. 27) Conzya. H.: Plast. Reconstr. Surg. 10:67, 1952: 28) Bruner: Arch. Otolaryng. Chicago, 60, 1954. 29) W. Krey. u. O. Bandtrozw.Laryng. Rhino. Otologie. $38: 7,1959$.

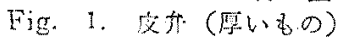

\section{付图説明}

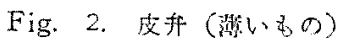

Fig. 3. No. 1 臹啳 1 日

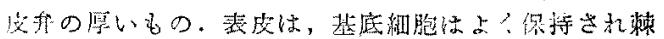

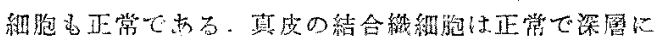

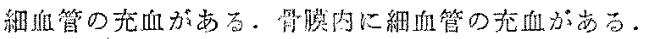

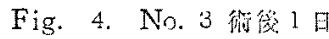

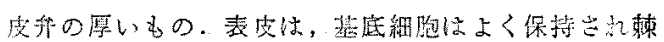

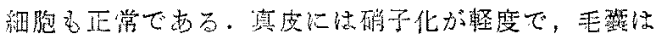

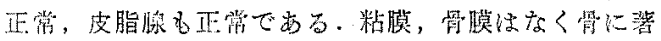
率はない。

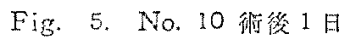

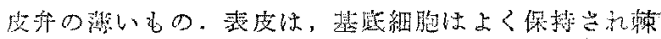

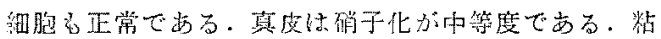

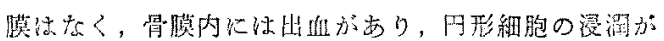
あᄒ

Fig. 6. No., 17 術後 2 日

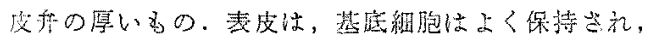

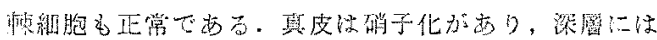

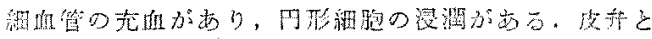

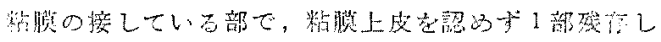

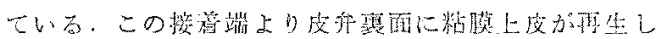

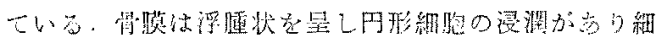

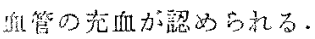

Fig. 7. No. 22 術倍 2 日

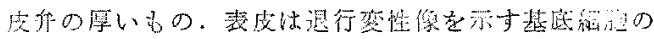

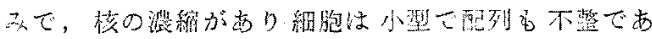

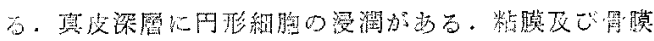

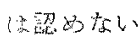

Fis. 8. No. 56 街後 3 月

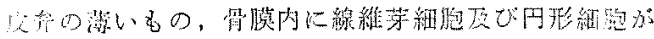

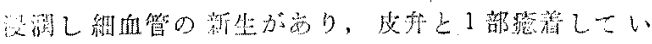

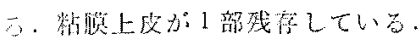

Fig. 9. No. 43 術㖟 3 日

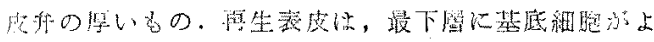

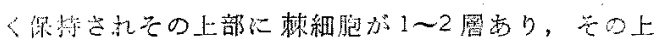

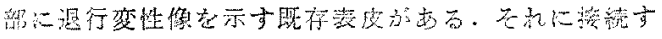

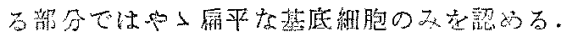


Fig. 10. No. 45 術後 3 日

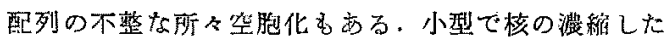

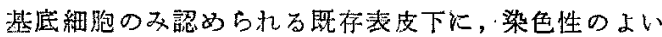

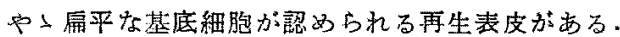

Fig. 11. No. 71 術後 5 日

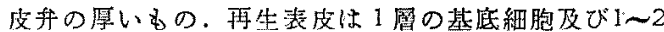
瀜の輠細胞があり，その上部に变性像を示す既存表皮

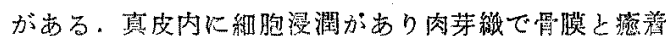
している。

Fig. 12. No. 71 術後 5 日 皮找の磨いもの，冒壁には搰膜を認めない，骨小管内 に線維芽細胞及び充血を認め，骨小管開口部には線維 芽細胞，円形細胞加增生し皮升内侵入している。

Fig. 13. No.67 衡後5日

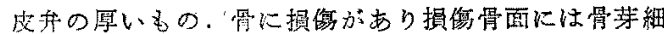

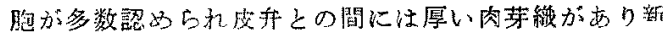
牛細血管の充租を多数みと方る。

Fig. 14. No. 69 術後 5 日

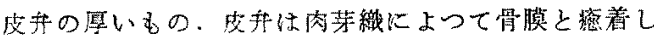
ている.

Fig. 15. No. 70 街輠 5 E

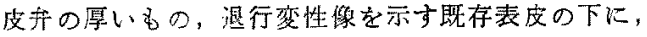
再生表皮があり，基底細胞はよく保持され，その上部

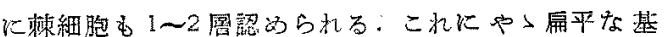
底細胞のみの部分が接続している。

Fig. 16. No. 97 術後 8 日

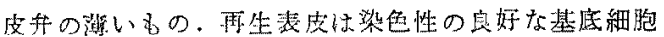

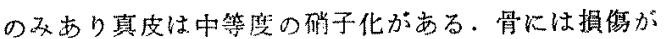

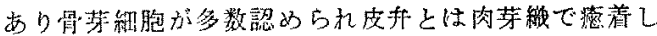
ている.

Fig. 17, No. 95 術後 8 日

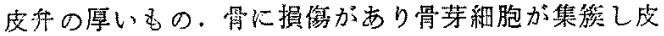
升との間には摩い肉芽織があり新生細血管の光血方す る1部は真皮内侵入している。骨の充血むるる。

Fig. 18. No. 98 班後 8 日

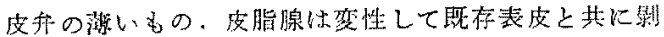
脱している。度长には邽生された表皮があり肥曆像を

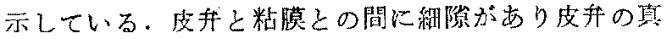
皮側に粘崼上皮が洅生している。

Fig. 19. No. 100 術後 8 日 皮我の潮いるの，表皮は肥暻像を示している，真皮は

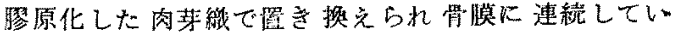
る.

Fig. 20. No. 130 術後 15 日

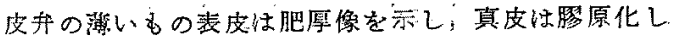

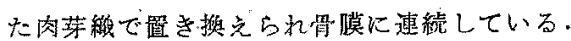

Fig. 21. No. 116 術後 15 日 粘荧上皮が残存し 1 部は糙嚆テステを形成している。

Fig. 22. No. 123 術後 15 日

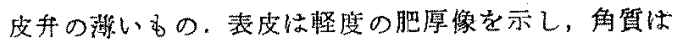
䟝離性でその上部に蒸維高度な皮脂腺が䟝脱してい る。罗小管内に線䊒芽細胞及び出血が認められる。皮 升とは少量の肉茅織で瘾着している。

Fig. 23，No. 113 術後 15 日

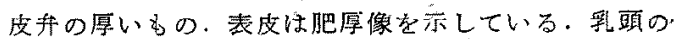
発青す著明であり粘膜テステがある。

Fig. 24. No. 114 断後 15 日

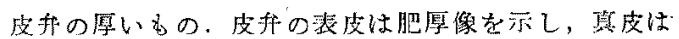

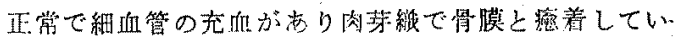
る。毛簬及び皮脂腺は正管である。

Fig. 25. No. 159 術後 30 日

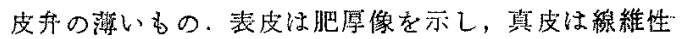

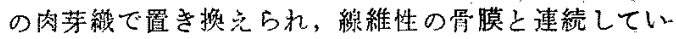
る.

Fig. 26, No. 147 畐後30日 皮升の厚いもの，驾胞化した皮脂腺が多数認めら九 る.

Fig. 27, No. 157 術鿏 30 日 皮弁の薄いる。. 表皮は肥厚像を示している.具皮は 線雓化した肉犽瀻で置き掺えられている，骨表面に山

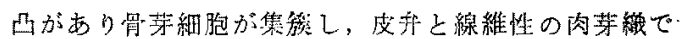
瘾合している。

Fig. 28, No. 145 衍後 30 日

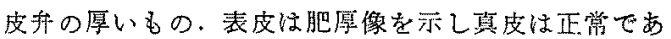

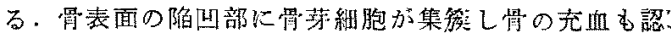
め的る。

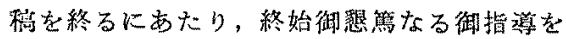
䦪わり，御校閣をいたざをました後藤修二教授 音びに田内久教授に心から感謝を致します

（原䖽到福 $=$ 炤和 35.3 .8 日） 


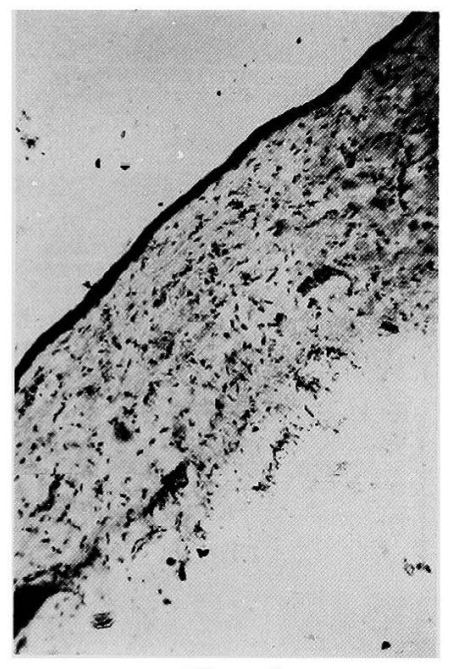

Fig. 1

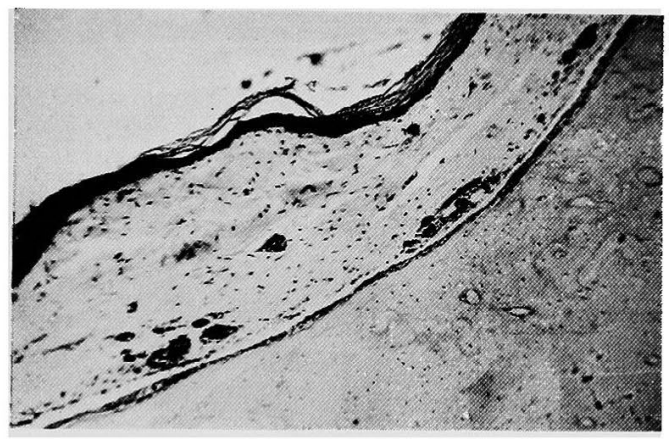

Fig. :

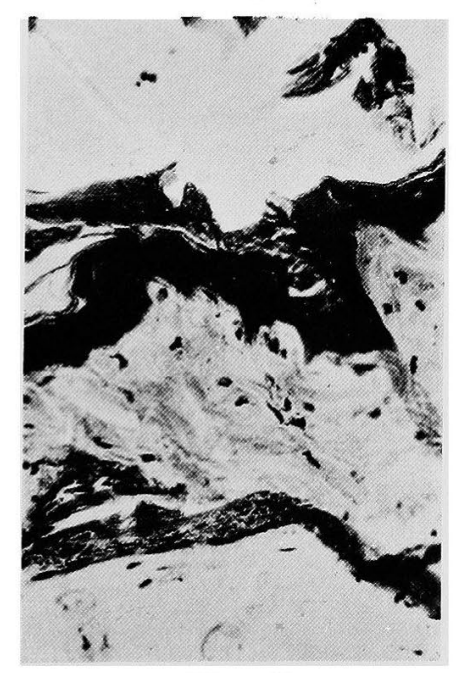

Fig. 5

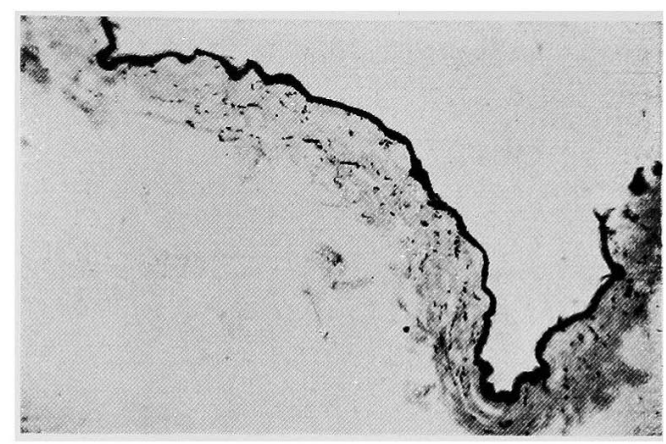

Fig. 2

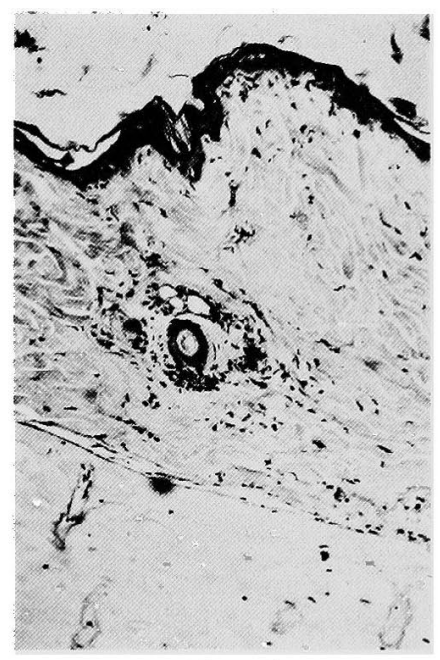

Fig. 4

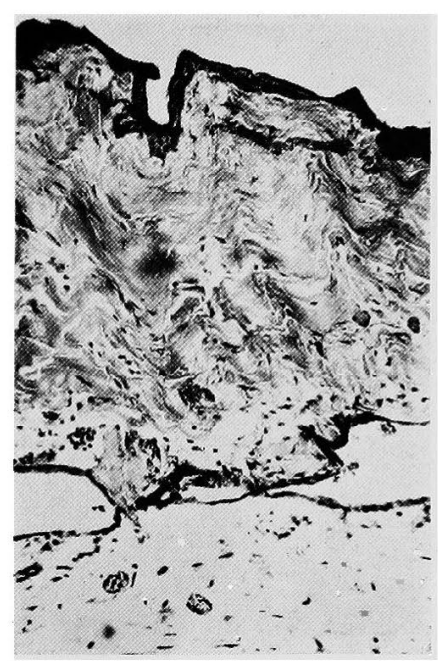

Fig. 6 
榎島論交付図（『)

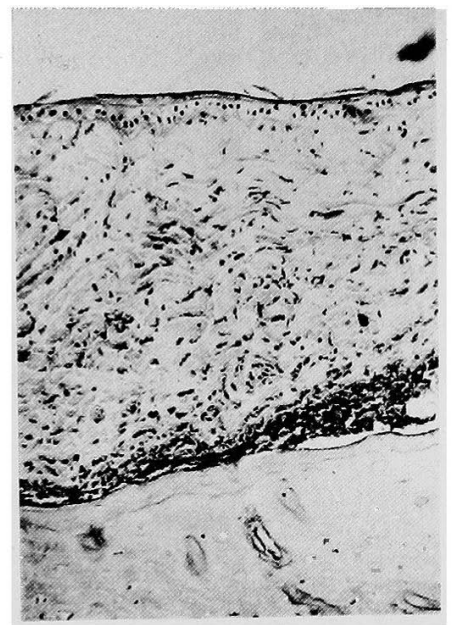

Fig. 7

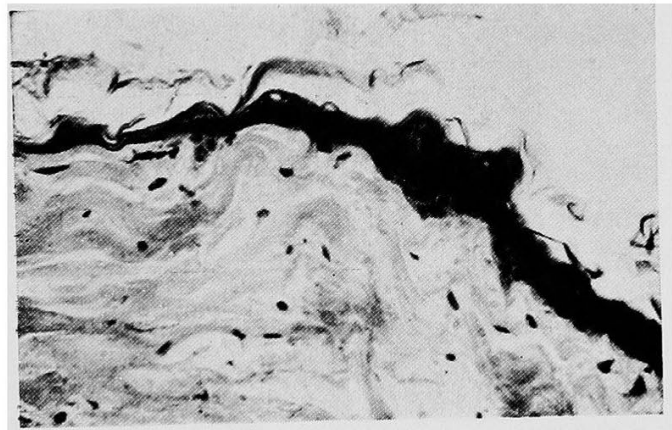

Fig. 9

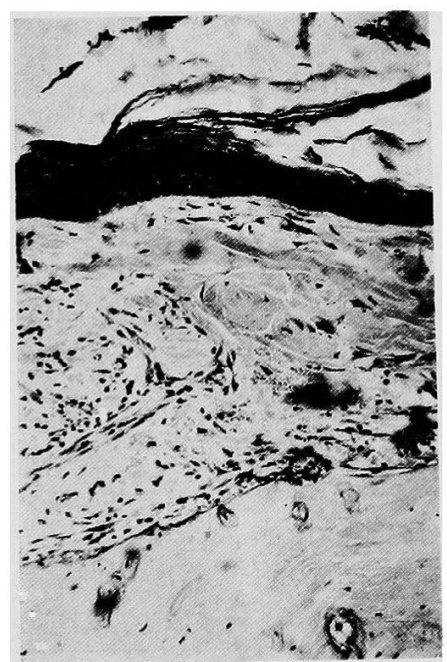

Fig. 11

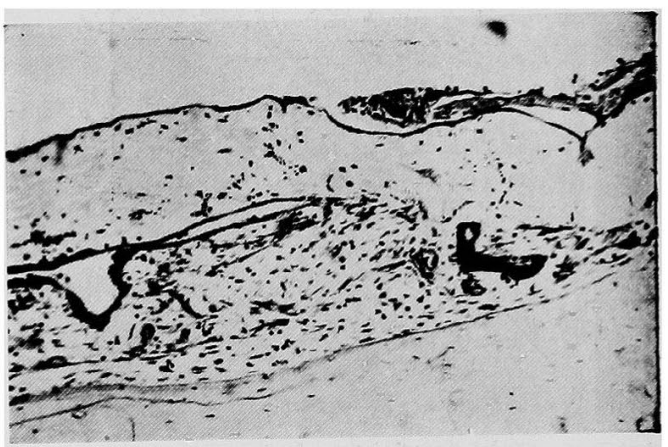

Fig. 8

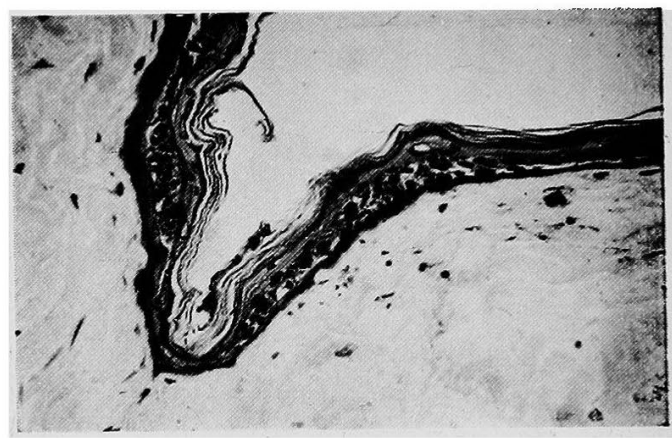

Fig. 10

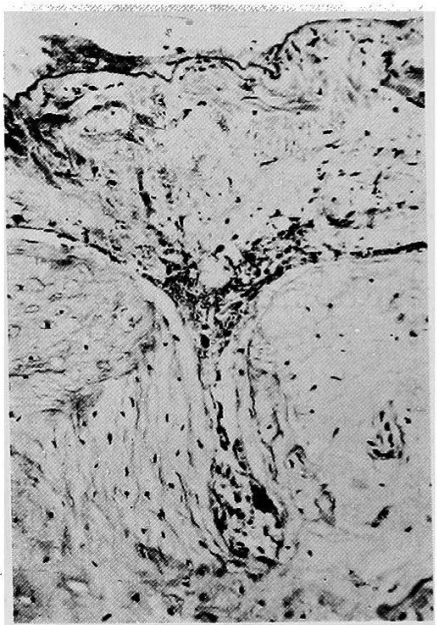

Fig. 12 
榎島論文付図（四）

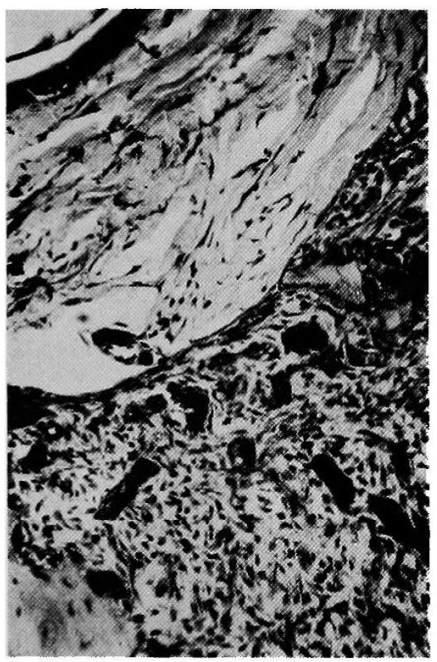

Fig. 13

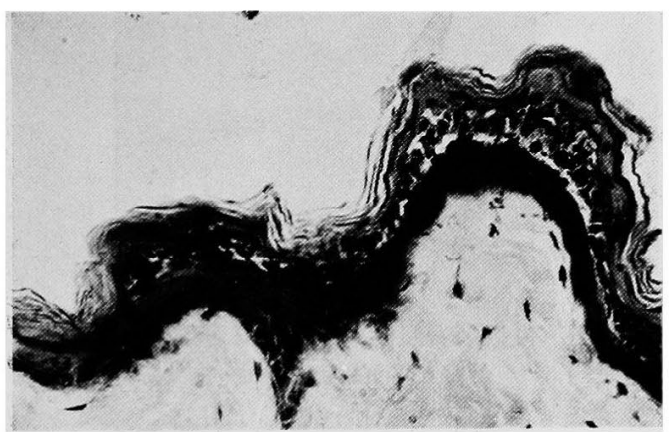

Fig. 15

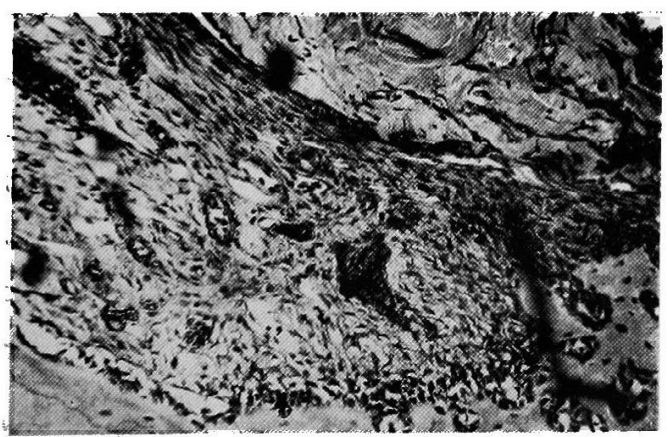

Fig. 17

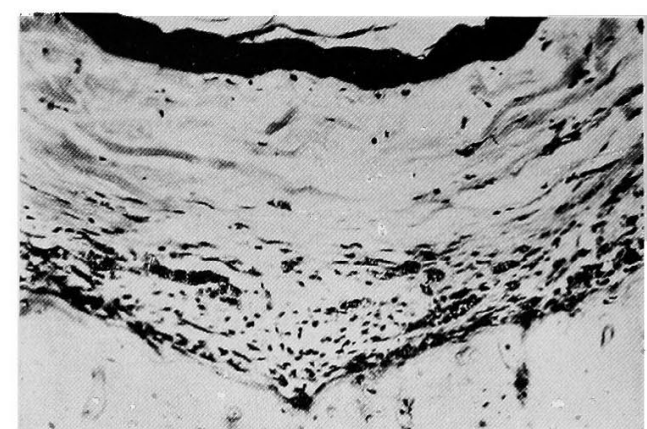

Fig. 14

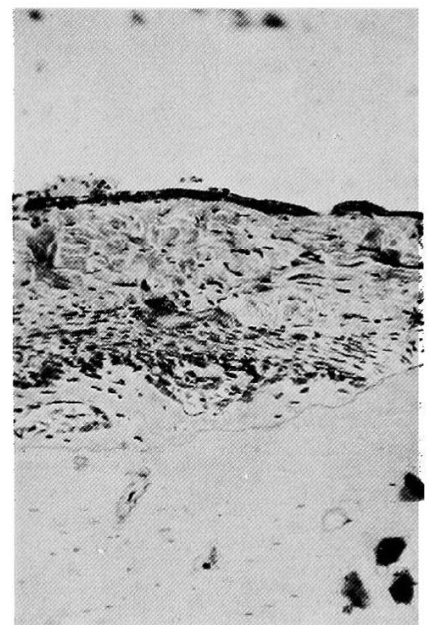

Fig. 16

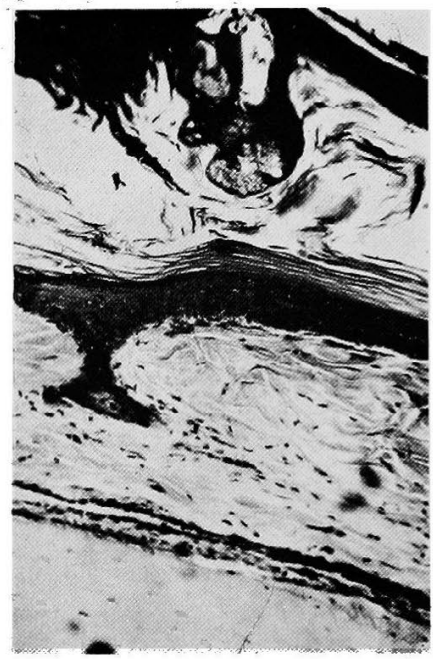

Fig. 18 
顺島論文付図 (N)

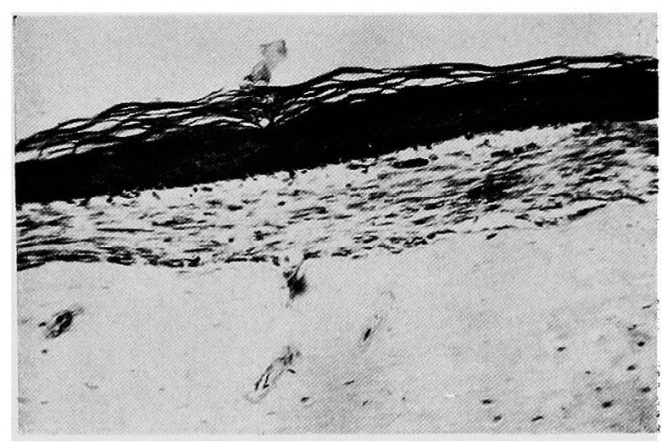

Fig. 19

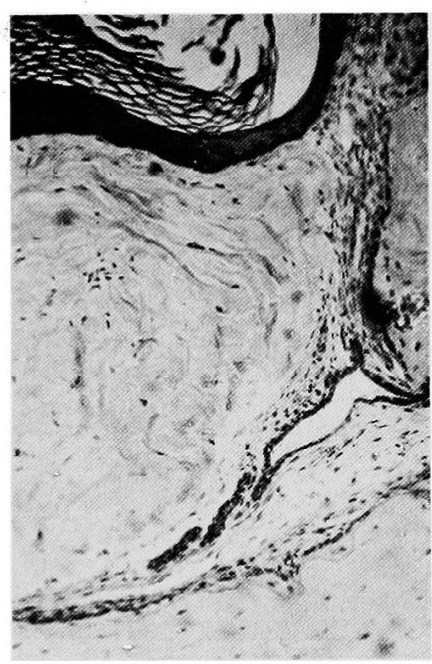

Fig. 21

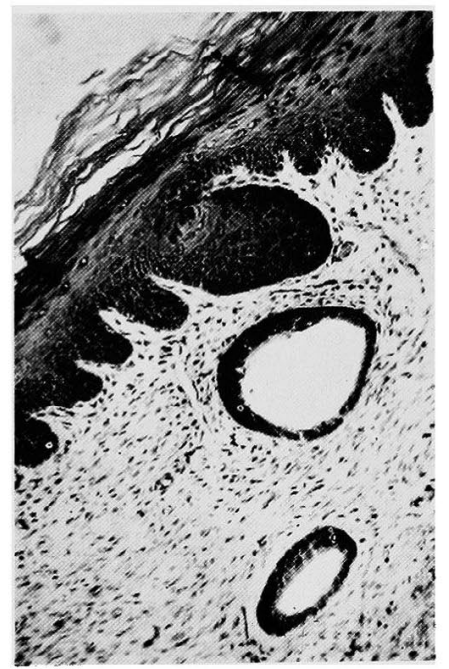

rig. 23

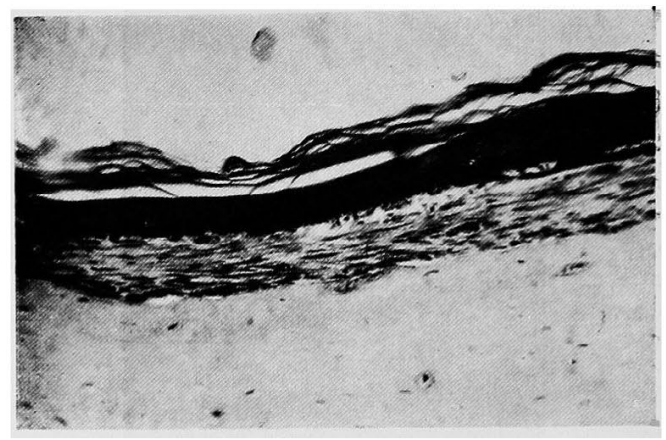

Fig. 20

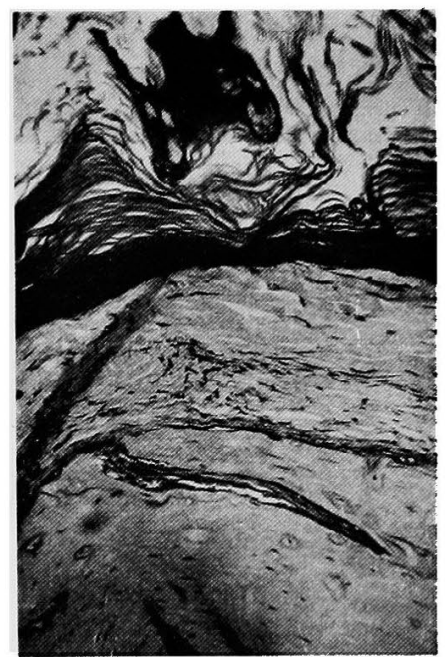

Fig. 22

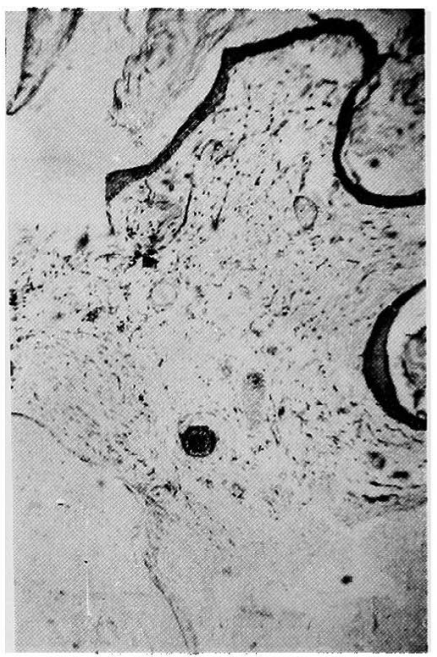

Fig. 24 


\section{䫅島論文付図 (V)}

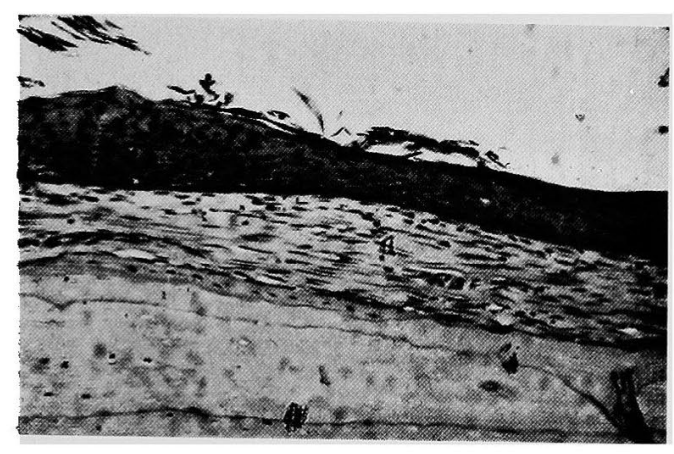

Fig. 25

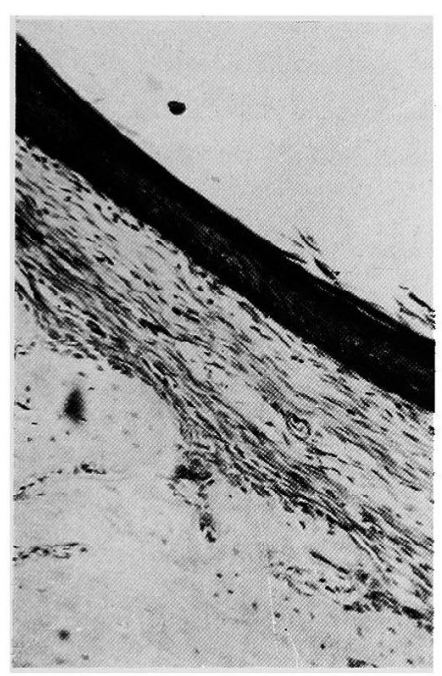

Fig. 27

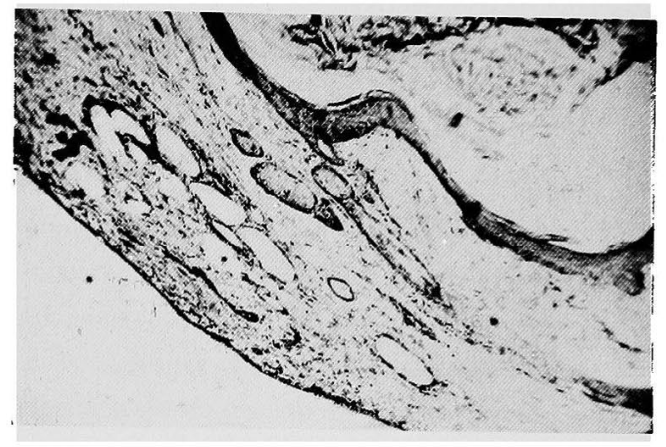

Fig. 26

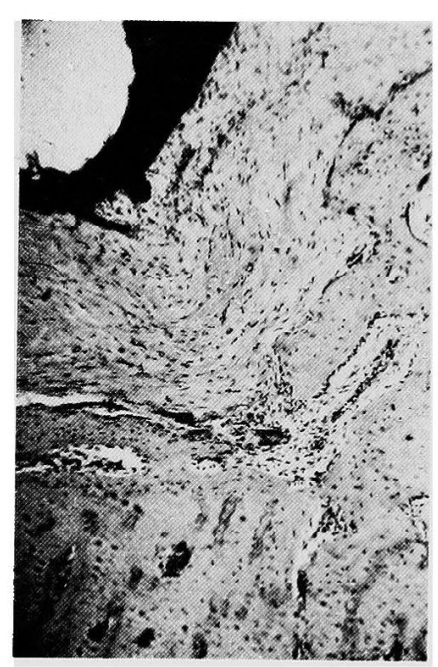

Fig. 28 